تأثير كلات آهن نانو بر غلظت عناصر غذايى كمصرف، رنخيزههاى فتوسنتزى برى و عملكرد كاهو (Lactuca sativa L.) در كشت بدون خاك

\author{
صبا ميرزاييان دهكردى'، شهرام كيانى" و عليرضا حسين يور
}

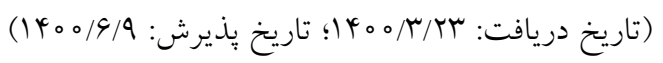

جكيده

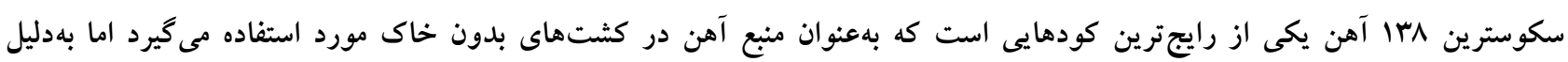

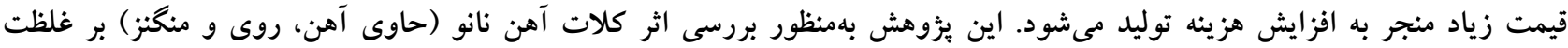

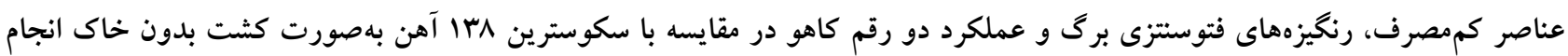

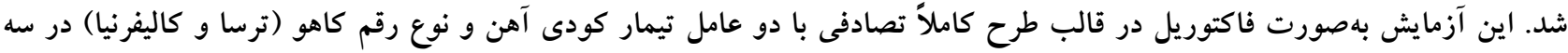

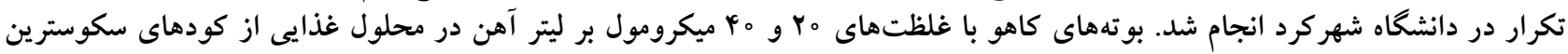

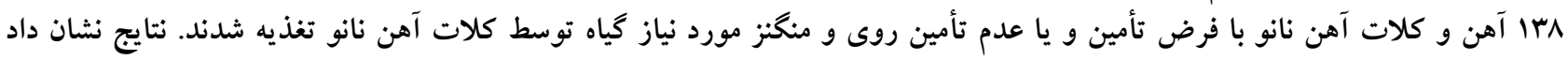

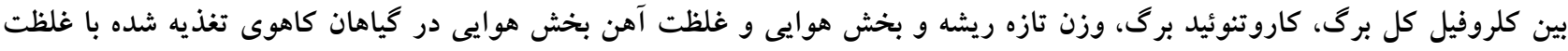

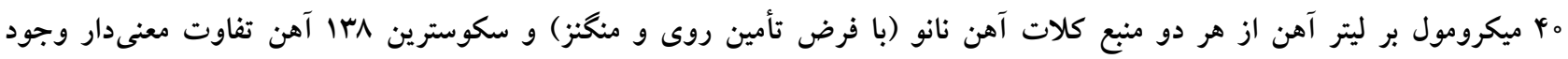

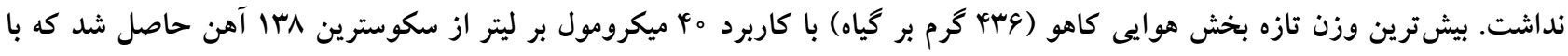

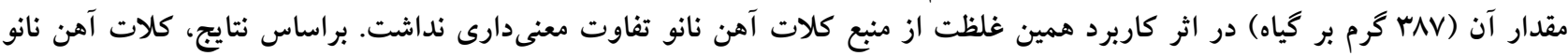

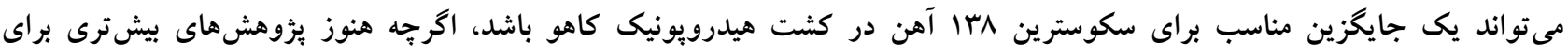

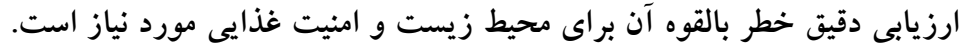

وازههاى كليدى: ارقام كاهو، سكوسترين ربا آهن، كلروفيل برگ، محلول غذايى

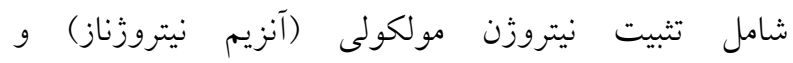

مقدمه

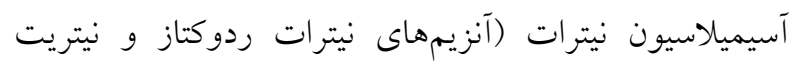

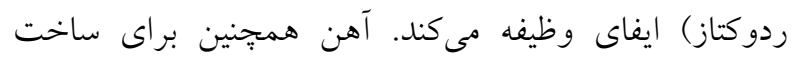

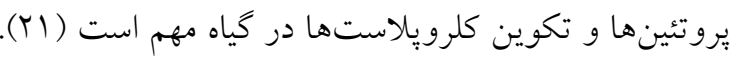

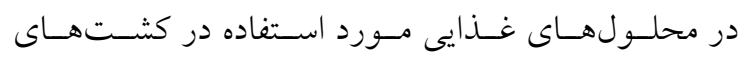

آهن از جمله عناصر كممصرف كياه است كه در بسيارى از

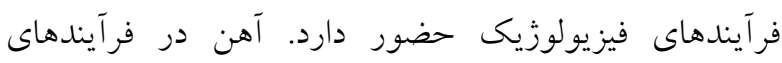

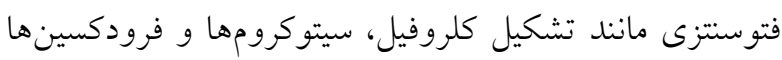
نقش داشته و در آسيميلاسيون (جذب و ساخت) نيتروزن سئن 
وجود نداشت. ييوندى و همكاران (YV) با مقايسه تأثير

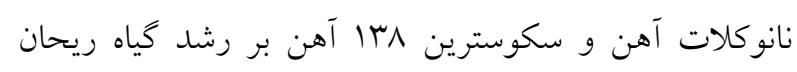

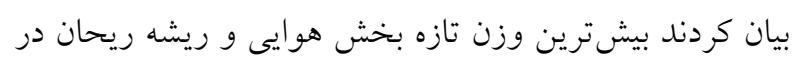

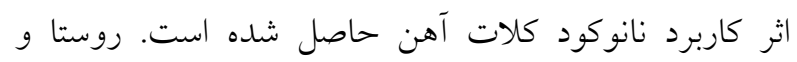
همكاران (T9) در بثزوهشهاى خود درباره تأثير كلات آهن

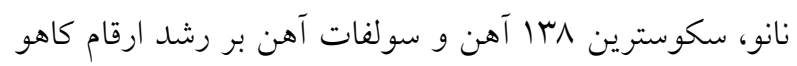

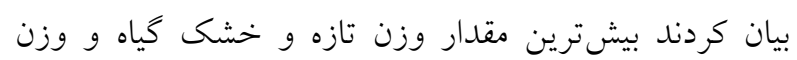

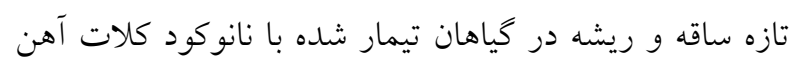

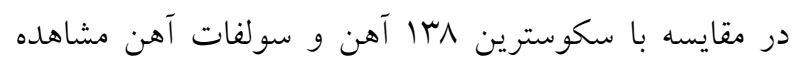

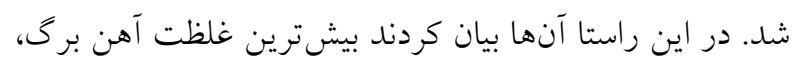
رنيخيزهاى فتوسنتزى برى و رشد رويشى در كياهان تيمار

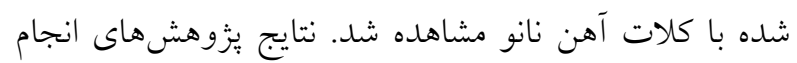

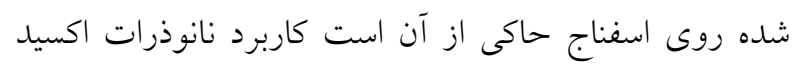

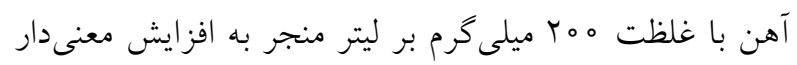

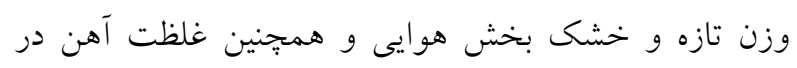

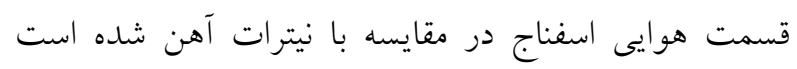

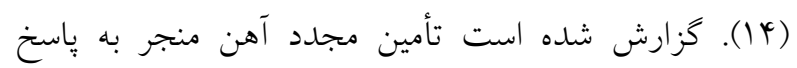

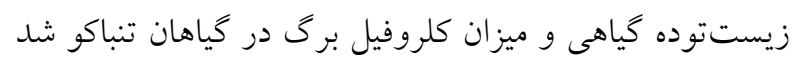

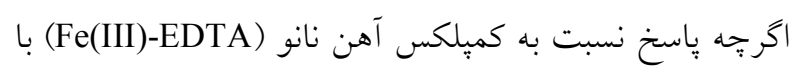

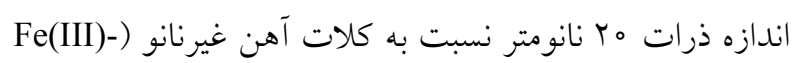

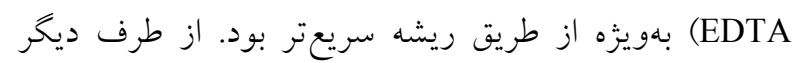

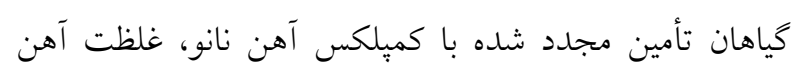
كمتر، اما كارايى مصرف آهن بيشترى نسبت به كياهان تأمين كمدين

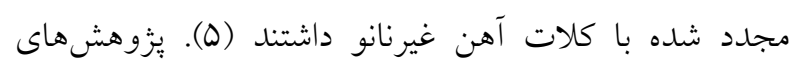

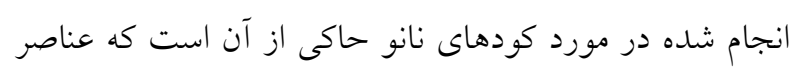

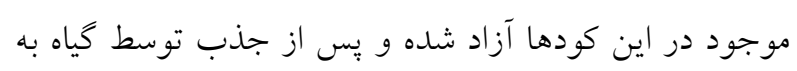

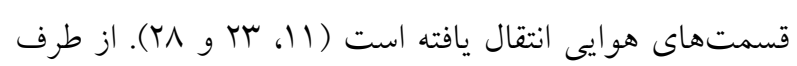

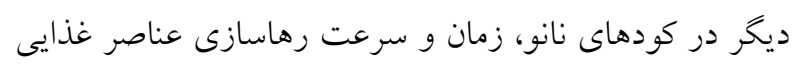

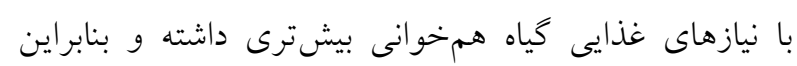

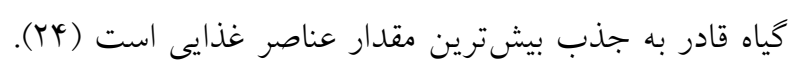

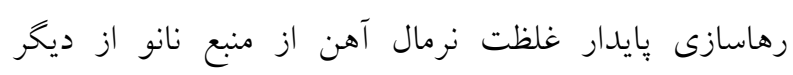

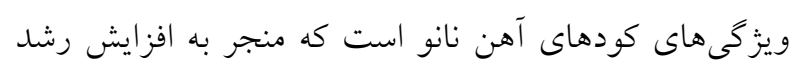

هيدرويونيك بهمنظور حفظ حلاليت آهن در محلول غذايى، از كلات كندههاى مصنوعى مانند Fe-DTPA Fe-EDTA و

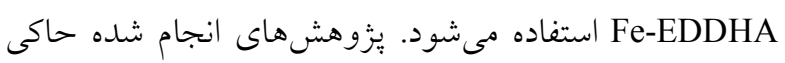

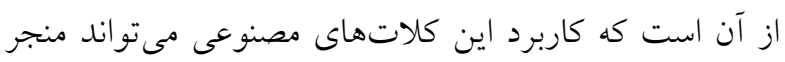

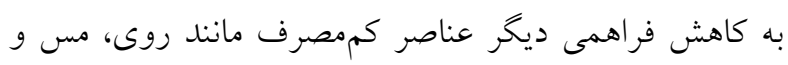

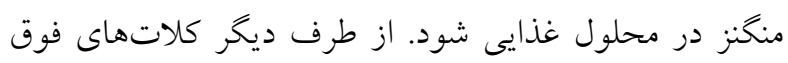

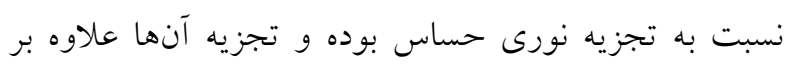

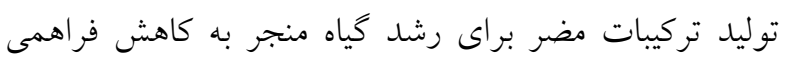

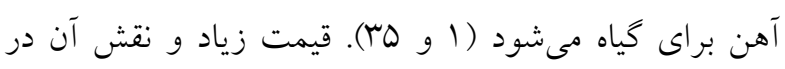

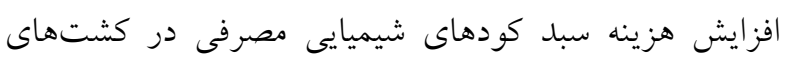

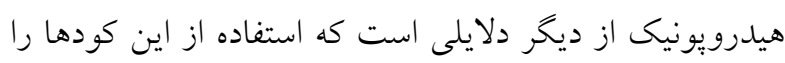
با ترديد مواجه مى سازد.

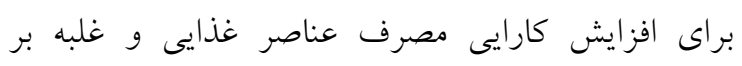

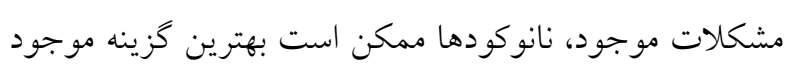
باشند. نانوكودها بهمنظور تنظيم رهاسازى عناصر غذايى بسته

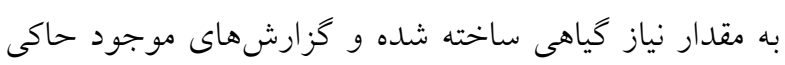

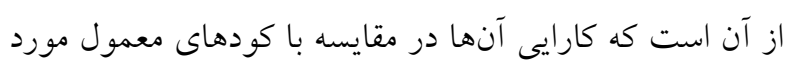

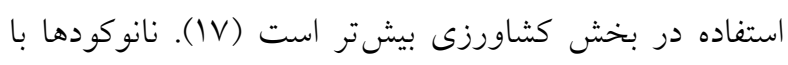

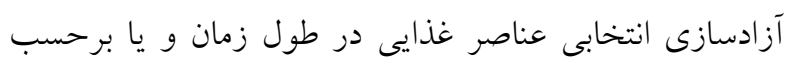
شرايط محيطى در كاهش آلودكىهاى زيستمحيطى نقش إنش

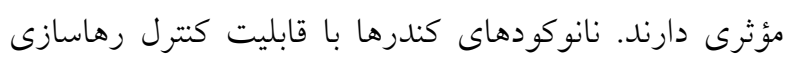
عناصر غذايى همجنين در بهبود كيفيت خاك از طريق كاهش

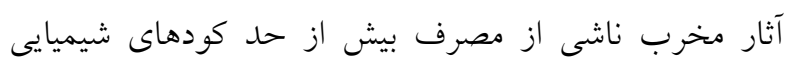

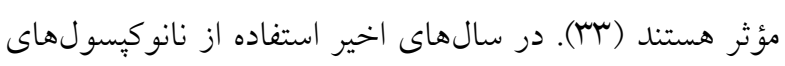
حاوى عناصر غذايى مورد نياز خياه با قابليت رهاسازى آرام

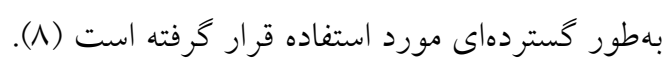

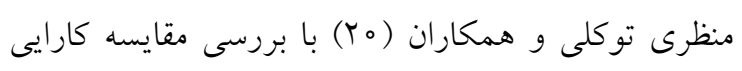

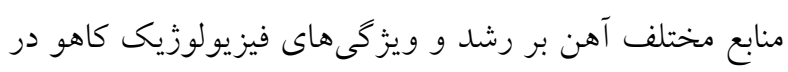

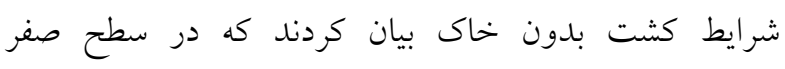

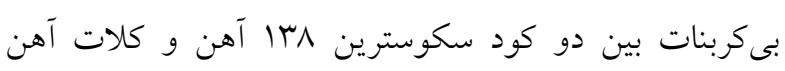

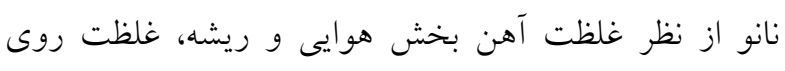

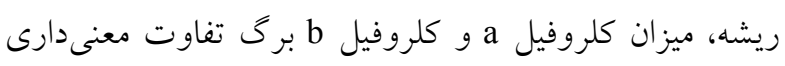


بر ليتر (در اين تيمار با فرض تـأمين بخشى از روى و منخخـز

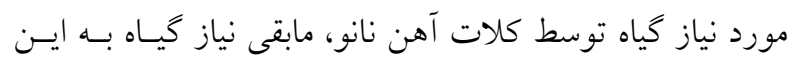

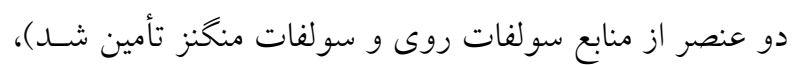

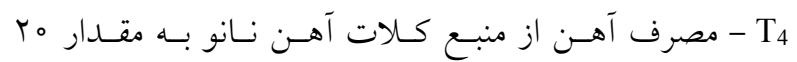

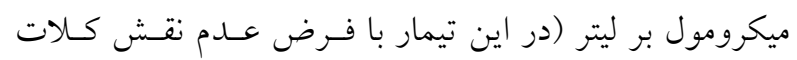

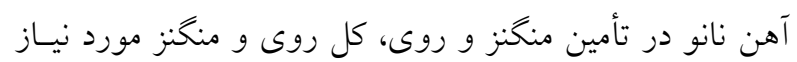

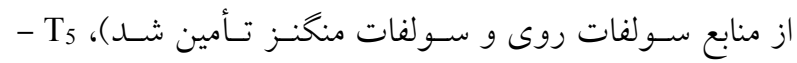

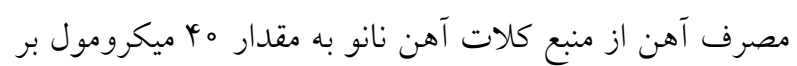

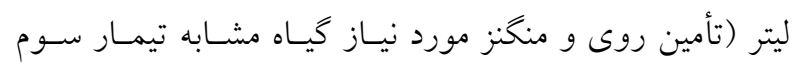

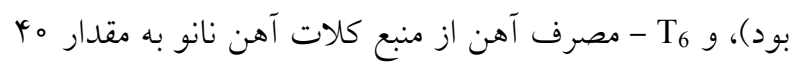

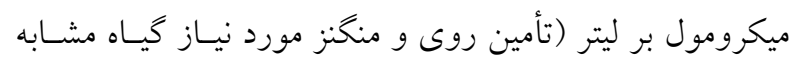

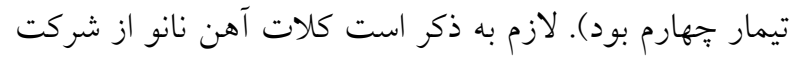

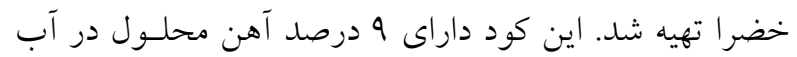
بوده و قابليت مصرف بهصورت خاكى، تغذيه برگى و كـود-

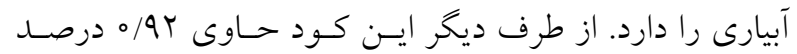

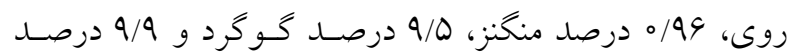

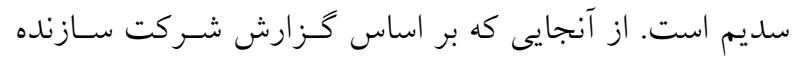

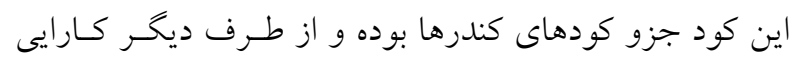

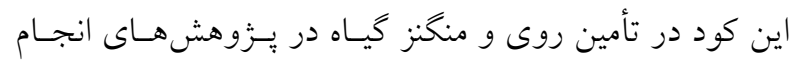

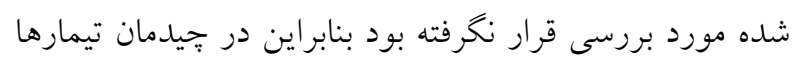
طورى عمل شد تا كارايى ايسن كـود در تـأمين روى و منخخنز مورد نياز گياه مورد سنجش قرار گيرد. از طرف ديخر با توجنه

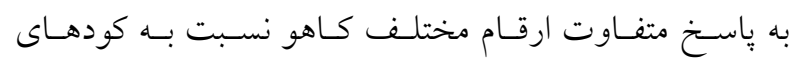

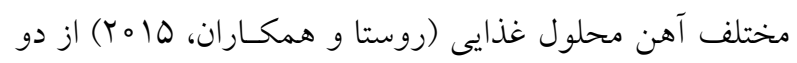

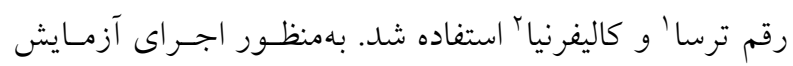
بذرهاى كاهو يس از ضـدعفونى توسط محلـول هييو كلريست سديم ا درصد، در سـينى كشـت نشـاى حساوى كوكوييـت و

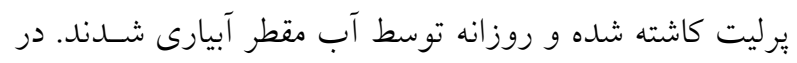
هغته اول مهرماه بَوس ا، نشاهـاى كـاهو در مرحلـه دو تـا سـهـ

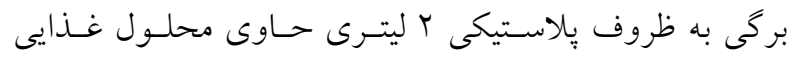

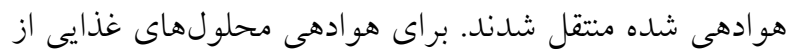

1. Teresa

2. California
كياه شده است (9). بر اساس يزوهشهاى انجام شده تحرى

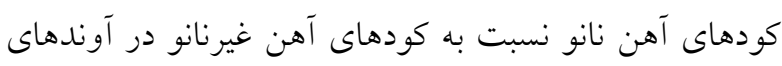

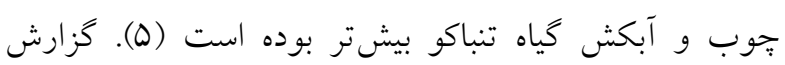
شده است افزودن نانوذرات اكسيدهاى آهن

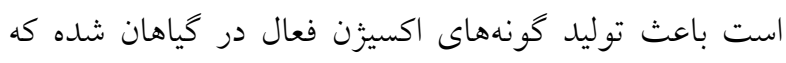
اين تركيبات بهعنوان يك مولكول بيامدهنده باعث تحريك

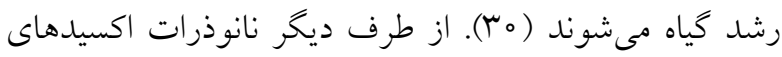

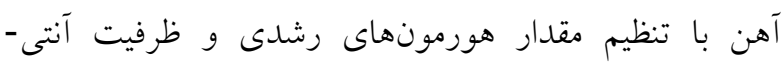

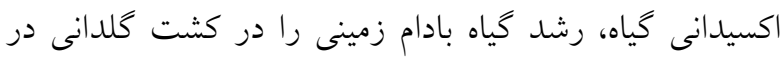

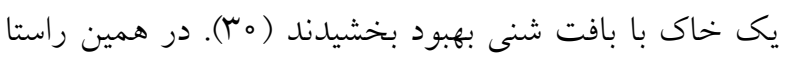

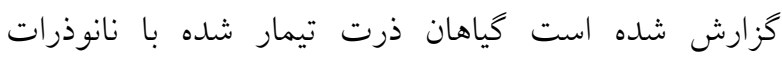

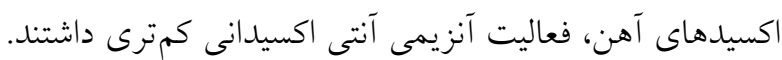
اين يافته نشاندهنده اين است كه تحت شرايط تنش آنش آهن آهن، كاربرد نانوذرات باعث ايجاد تنش كمترى ناشى از اكسيزن فعال در مقايسه با كاربرد Fe-DTPA در ذرت شده است (9). با توجه به موارد فوق يُزوهش حاضر سعى دارد كارد كارايى

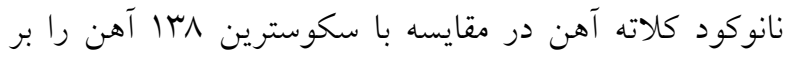

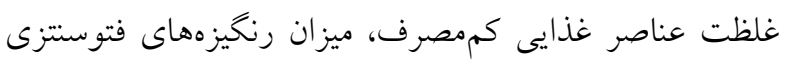

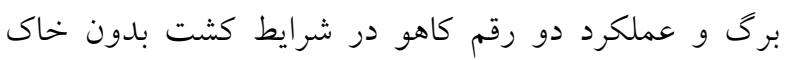
مورد بررسى قرار دهد.

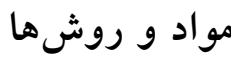

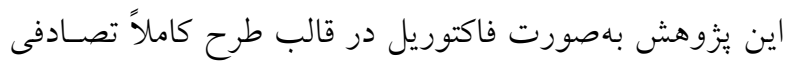

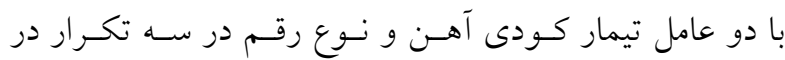

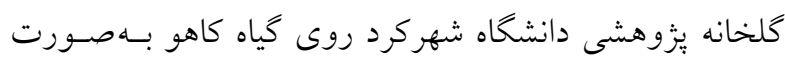

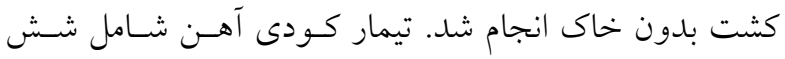

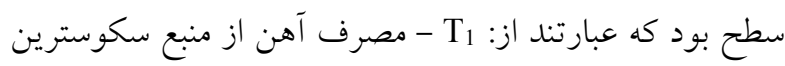

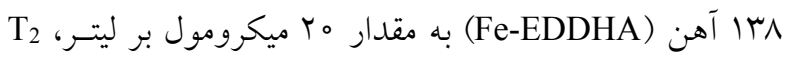

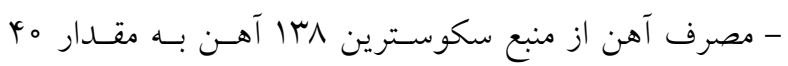

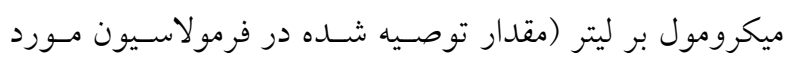

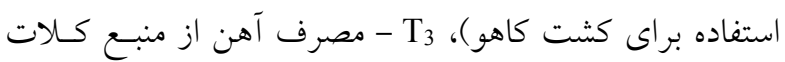

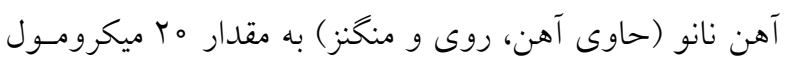


جدول ا. برخى از ويزَى هاى شيميايى آب مورد استفاده براى تهيه محلول غذايى.

Table 1. Some chemical properties of the water used for the preparation of nutrient solution.

\begin{tabular}{|c|c|c|c|c|c|c|c|}
\hline 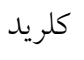 & نيتروزن نيتراته & منيزيم & كلسيم & يتاسيم & سديم & بِ.هاش & رسانايى الكتريكى \\
\hline $\mathrm{Cl}^{-}$ & $\mathrm{N}-\mathrm{NO}_{3}{ }^{-}$ & $\mathrm{Mg}^{2+}$ & $\mathrm{Ca}^{2+}$ & $\mathrm{K}^{+}$ & $\mathrm{Na}^{+}$ & $\mathrm{pH}$ & EC \\
\hline & \multicolumn{5}{|c|}{$\left(\mathrm{mmol} \mathrm{L}^{-1}\right)$} & & $\left(\mathrm{dS} \mathrm{m}^{-1}\right)$ \\
\hline 1.3 & 0.23 & 0.8 & 1.5 & 0.1 & 0.2 & 7.6 & 0.45 \\
\hline
\end{tabular}

كترل شده و در صورت كاهش حجم، با استفاده از آب مقطر به حجم اوليه رسانده شد. pH محلول غذايى نيز هر دو روز يكبار اندازهيرى شده و با افزودن اسيد سولفوريك و يا سود

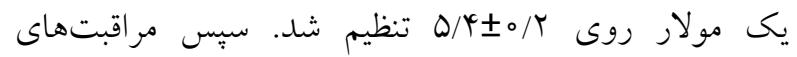
زراعى معمول در حين دوره داشت در كلخانه تا زمان

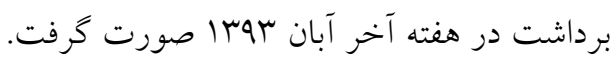

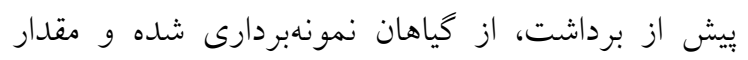

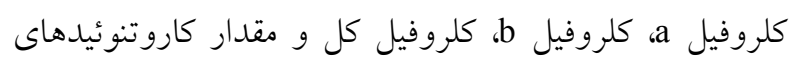

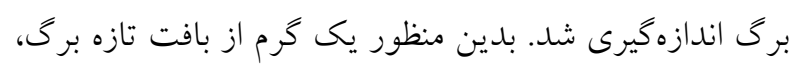

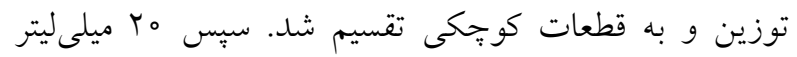

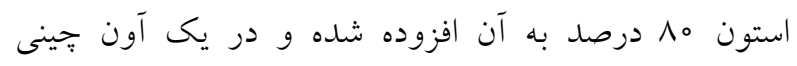

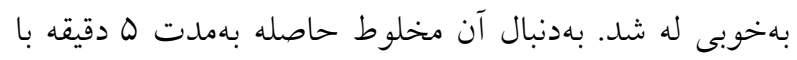
دور 0مه دور بر دقيقه سانتريفيوز شده و محلول روئين به

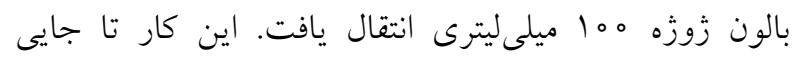

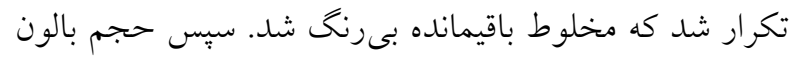
زوزه با استون •م درصد به حجم رسانده شد. در نهايت ميزان

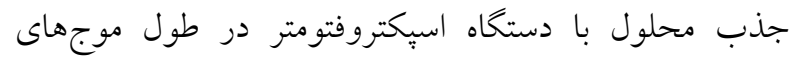

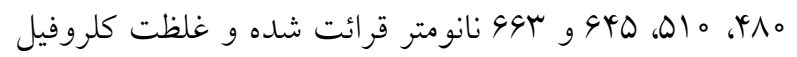

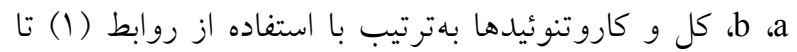
(l) (l) محاسبه شد: (l)

Chlorophyll a $\left(\mathrm{mg} \mathrm{g}^{-1}\right)=$

$\left[12.7\left(\mathrm{OD}_{663}\right)-2.69\left(\mathrm{OD}_{645}\right)\right] \times \mathrm{V} \times \mathrm{W} / 1000$

Chlorophyll $\mathrm{b}\left(\mathrm{mg} \mathrm{g}^{-1}\right)=$

$\left[22.9\left(\mathrm{OD}_{645}\right)-4.68\left(1 \mathrm{OD}_{663}\right)\right] \times \mathrm{V} \times \mathrm{W} / 1000$

Total chlorophyll $\left(\mathrm{mg} \mathrm{g}^{-1}\right)=$

$\left[20.2\left(\mathrm{OD}_{645}\right)+8.02\left(\mathrm{OD}_{663}\right)\right] \times \mathrm{V} \times \mathrm{W} / 1000$

Carotenoids $\left(\mathrm{mg} \mathrm{g}^{-1}\right)=$

$\left[7.6\left(\mathrm{OD}_{480}\right)-1.49\left(\mathrm{OD}_{510}\right)\right] \times \mathrm{V} \times \mathrm{W} / 1000$
يُمٍ آكواريوم استفاده شد. در ضمن براى هر تيمار آزمايشى r ظرف در نظر كرفته شده و در درون هر ظـرف يـك نشـاى

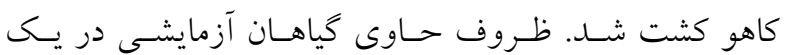

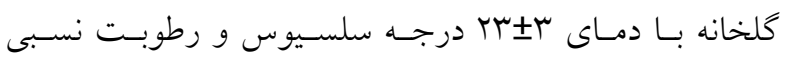
19. 90 درصد بر روى سكو جيده شدند. براى تهيه محلول غذايى از آب شرب داند دانشخاه شهركرد

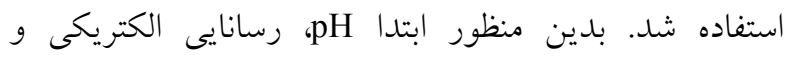

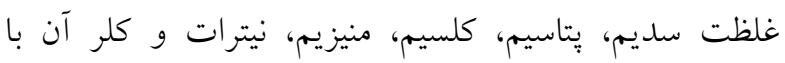
استفاده از روشهاى معمول اندازهيرى شد (Y). فرمولاسيون عناصر غذايى مورد استفاده براى تهيه محلول غذايى بدين

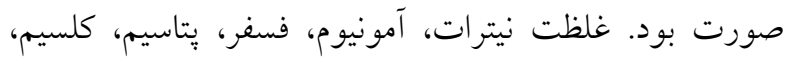

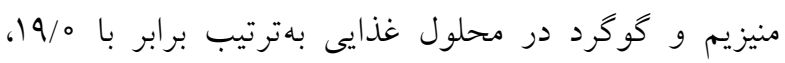
1/TD غلظت عناصر غذايى كممصرف براى مس، بور، منكنز، روى و

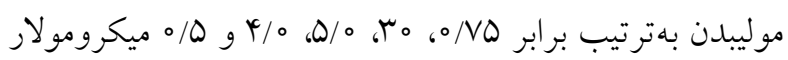

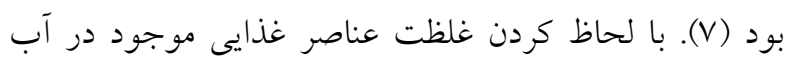
(جدول ()، محاسبات لازم براى حصول به غلظتهاى مورد

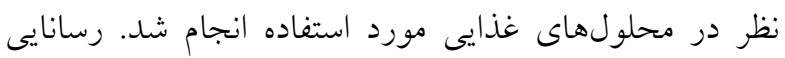

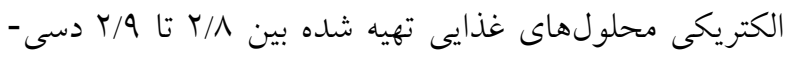
زيمنس بر متر بود. همجنين pH محلولهاى غذايى با استفاده

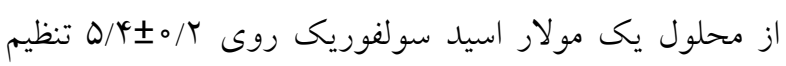

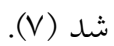
پِ از انتقال نشاهاى كاهو به ظروف حاوى محلول

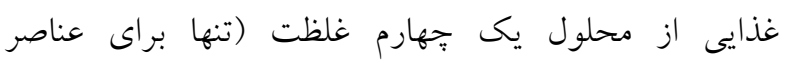

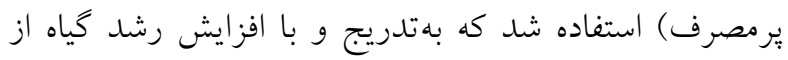

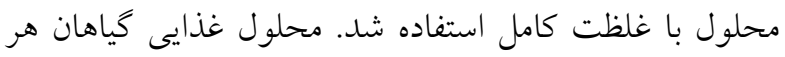
هفته تعويض شده و در اين مدت، سطح محلول هر روز 
جدول r. تجزيه واريانس (ميانخين مربعات) تأثير تيمار كودى و رقم بر غلظت عناصر غذايى در ريشه و بخش هوايى كاهو.

Table 2. Variance analysis (mean squares) for the effects of fertilizer treatment and cultivar on shoot and root nutrients concentration

\begin{tabular}{|c|c|c|c|c|c|c|c|c|}
\hline \multicolumn{4}{|c|}{ بخش هوايى } & \multicolumn{3}{|c|}{ ريشه } & \multirow{3}{*}{ درجه آزادى } & \multirow[t]{3}{*}{$\begin{array}{l}\text { منابع تغيير } \\
\text { S.O.V }\end{array}$} \\
\hline مس & روى & منخگنز & آهن & روى & منكنز & آهن & & \\
\hline $\mathrm{Cu}$ & $\mathrm{Zn}$ & $\mathrm{Mn}$ & $\mathrm{Fe}$ & $\mathrm{Zn}$ & $\mathrm{Mn}$ & $\mathrm{Fe}$ & & \\
\hline $7.59^{* *}$ & $731^{* *}$ & $406^{* *}$ & $9154^{* *}$ & $20594^{* *}$ & $538^{* *}$ & $233462^{* *}$ & 5 & $\begin{array}{c}\text { تيمار كودى } \\
\text { Fertilizer treatment }\end{array}$ \\
\hline $1.91^{\mathrm{ns}}$ & $81.0^{\mathrm{ns}}$ & $128^{\mathrm{ns}}$ & $107^{\mathrm{ns}}$ & $1763^{\mathrm{ns}}$ & $163^{\mathrm{ns}}$ & $2145^{\mathrm{ns}}$ & 1 & $\begin{array}{c}\text { رقم كاهو } \\
\text { Lettuce cultivar }\end{array}$ \\
\hline $0.18^{\mathrm{ns}}$ & $59.8^{\mathrm{ns}}$ & $3.4^{\mathrm{ns}}$ & $5824^{\mathrm{ns}}$ & $2377^{\mathrm{ns}}$ & $43^{\mathrm{ns}}$ & $40342^{\mathrm{ns}}$ & 5 & $\begin{array}{c}\text { تيمار كودى × رقم كاهو } \times \text { Fertilizer treatment } \times \text { Lettuce } \\
\text { cultivar }\end{array}$ \\
\hline 0.38 & 63.2 & 31.5 & 2559 & 925 & 103 & 34180 & 24 & $\begin{array}{l}\text { Uط } \\
\text { Error }\end{array}$ \\
\hline
\end{tabular}

غير معنى دار، "مs معنى دار در سطح ا درصد

${ }^{n s}$ Non significant, ${ }^{* *}$ Significant at $1 \%$

غلظت آهن، منخنز و روى ريشه كاهو در سطح احتمال يك درصد معنىدار شد. درحالى كه اثر رقم كاهو و برهمكنش تيمار كودى با رقم كاهو بر غلظت آهن، منگنز و روى ريشه

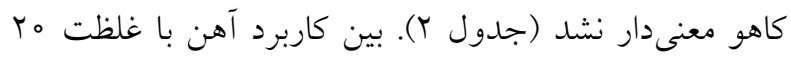
ميكرومول بر ليتر از منبع كلات آهن نانو (با فرض تأمين بخشى از روى و منگنز، تيمار T3) با كاربرد آهن با همين غلظت از منبع سكوسترين ^با آهن (تيمار T1) از نظر غلظت آهن ريشه تفاوت معنىدارى وجود نداشت. در همخوانى با نتايج اين يزوهش، منظرى توكلى و همكاران (Yo) عنوان كردند در سطح صفر بىكربنات، تفاوت غلظت براى آهن و روى ريشه بين گياهان كاهوى تغذيه شده با سكوسترين یما

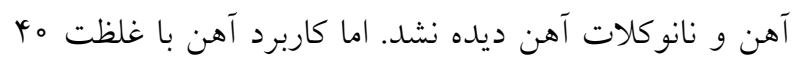
ميكرومول بر ليتر آهن از منبع كلات آهن نانو (با فرض تأمين بخشى از روى و منخنز، تيمار T5) موجب افزايش معنى دار غلظت آهن ريشه نسبت به كاربرد آهن با همين غلظت از منبع سكوسترين ^شا (تيمار T2) آهن شد (جدول شا). اين مسئله نشاندهنده آن است كه در غلظت ه ب ميكرومول بر ليتر، كلات آهن نانو توانايى بيشترى در تأمين آهن مورد نياز كياه در مقايسه با سكوسترين ^با آهن داشته است.
در اين روابط OD: ميزان جذب در طول موجهاى مورد نظر، : حجم محلول نهايى برحسب ميلىليتر و W: وزن تازه برى برحسب گرم است (اس). بس از كذشت ^ هفته بوتهها برداشت شده و بخش هوايى و ريشه كياه از يكديخر جدا شده و وزن تازه نمونهها توسط ترازوى رقومى اندازهگيرى شد. نمونهها يس از شستشو توسط آب معمولى و آب مقطر بهمدت VY ساعت در آون در دماى مo درجه سلسيوس قرار داده شد تا خشك شوند. بدنبال آن نمونهها با استفاده از آسياب برقى خرد شده و غلظت آهن، منخنز، مس و روى موجود در نمونهها يس از هضم خشك و تركيب با HCl با استفاده از دستخاه جذب اتمى اندازهذيرى شد (0). نتايج حاصله توسط نرمافزار آمارى (SAS) تجزيه و تحليل شده و براى مقايسه و دستهبندى ميانكينها از آزمون حداقل تفاوت معنىدار (LSD) در سطح احتمال ه درصد استفاده شد.

نتايج و بحث تأثير تيمارهاى آزمايشى بر غلظت آهن، منگنز و روى ريشه كاهو: نتايج تجزيه واريانس نشان داد اثر تيمار كودى بر 


$$
\text { جدول r. مقايسه ميانخين تأثير تيمار كودى بر غلظت عناصر غذايى ريشه و بخش هوايى كاهو. }
$$

Table 3. Mean comparisons of the effect of fertilizer treatment on shoot and root nutrients concentration in lettuce.

\begin{tabular}{|c|c|c|c|c|c|c|c|c|}
\hline تيمار كودى & غلظت آهن & آهن & 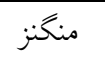 & ل - ل & آهن & منزخنز & 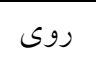 & مس \\
\hline \multirow[t]{3}{*}{ Fertilizer treatment } & \multirow{3}{*}{$\begin{array}{l}\text { Fe concentration } \\
(\mu \mathrm{mol} \mathrm{L}-1)\end{array}$} & $\mathrm{Fe}$ & $\mathrm{Mn}$ & $\mathrm{Zn}$ & $\mathrm{Fe}$ & $\mathrm{Mn}$ & $\mathrm{Zn}$ & $\mathrm{Cu}$ \\
\hline & & \multicolumn{7}{|c|}{$\left(\mathrm{mg} \mathrm{kg}^{-1}\right)$} \\
\hline & & \multicolumn{3}{|c|}{ ريشه Root } & \multicolumn{4}{|c|}{ بخش هوايى Shoot } \\
\hline $\mathrm{T}_{1}$ & 20 & $585^{\mathrm{d}}$ & $19.0^{\mathrm{c}}$ & $46.0^{\mathrm{e}}$ & $123^{\mathrm{c}}$ & $12.2^{\mathrm{c}}$ & $30.0^{\mathrm{c}}$ & $4.7^{\mathrm{a}}$ \\
\hline $\mathrm{T}_{2}$ & 40 & $765^{\mathrm{cd}}$ & $30.5^{\mathrm{bc}}$ & $97.3^{\mathrm{de}}$ & $187^{\mathrm{bc}}$ & $14.4^{\mathrm{c}}$ & $34.2^{\mathrm{c}}$ & $4.2^{\mathrm{b}}$ \\
\hline $\mathrm{T}_{3}$ & 20 & $670^{\text {cd }}$ & $35.6^{\mathrm{b}}$ & $108.1^{\mathrm{cd}}$ & $194^{\mathrm{bc}}$ & $30.7^{\mathrm{a}}$ & $50.3^{\mathrm{ab}}$ & $4.3^{\mathrm{b}}$ \\
\hline $\mathrm{T}_{4}$ & 20 & $844^{\text {bc }}$ & $37.3^{\mathrm{ab}}$ & $156.9^{\mathrm{bc}}$ & $239^{a}$ & $32.0^{\mathrm{a}}$ & $47.4^{\mathrm{b}}$ & $2.6^{\mathrm{c}}$ \\
\hline $\mathrm{T}_{5}$ & 40 & $992^{\mathrm{ab}}$ & $47.9^{\mathrm{a}}$ & $192.2^{\mathrm{ab}}$ & $207^{\mathrm{ab}}$ & $25.8^{\mathrm{ab}}$ & $58.6^{\mathrm{a}}$ & $2.9^{c}$ \\
\hline $\mathrm{T}_{6}$ & 40 & $1109^{a}$ & $36.7^{\mathrm{b}}$ & $213.3^{\mathrm{a}}$ & $168^{\mathrm{bc}}$ & $23.9^{\mathrm{b}}$ & $52.0^{\mathrm{ab}}$ & $1.9^{\mathrm{c}}$ \\
\hline
\end{tabular}

تأس

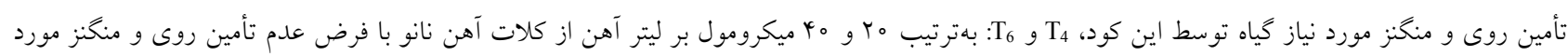

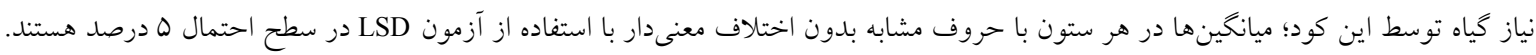
$\mathrm{T}_{1}$ and $\mathrm{T}_{2}: 20$ and $40 \mu \mathrm{mol} \mathrm{L} \mathrm{L}^{-1}$ of Fe from Fe-EDDHA, respectively, $\mathrm{T}_{3}$ and $\mathrm{T}_{5}: 20$ and $40 \mu \mathrm{mol} \mathrm{L}^{-1}$ of Fe from nano iron chelate, respectively

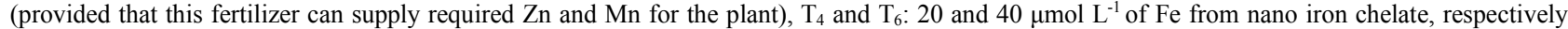
(provided that this fertilizer is not able to supply required $\mathrm{Zn}$ and $\mathrm{Mn}$ for the plant); Data in each column with the same letter are not statistically different at 0.05 probability level based on LSD Test.

و منگنز در تيمار T6 و به دنبال آن كاهش رشد ريشه باشد.

تأثير تيمارهاى آزمايشى بر غلظت آهن، منگنز، روى و مس بخش هوايى كاهو: نتايج تجزيه واريانس نشان داد اثر تيمار كودى بر غلظت آهن، منخنز، روى و مس بخش هوايى كاهو در سطح احتمال يك درصد معنىدار شد. درحالى كه اثر رقم كاهو و برهمكنش تيمار كودى با رقم كاهو بر غلظت آهن، منگنز، روى و مس بخش هوايى كاهو معنىدار نشد (جدول

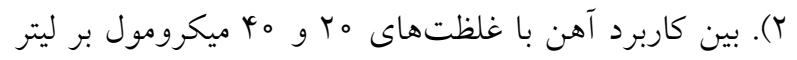
آهن از منبع كلات آهن نانو (با فرض تأمين بخشى از روى و منكنز، بهترتيب در تيمارهاى T3 و Th

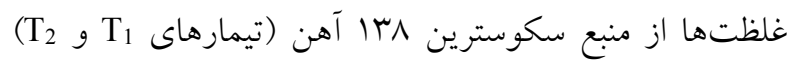
از نظر غلظت آهن بخش هوايى تفاوت معنىدارى وجود نداشت (جدول س). اين نتيجه نشاندهنده آن است كه كات آلات آهن نانو همجهون سكوسترين ^با آهن در تأمين آهن مورد نياز بخش هوايى كياه مؤثر عمل كرده است. در همخوانى با نتايج اين يزوهش كزارش شده است در سطح صفر بى كربنات
كاربرد آهن با غلظتهاى مr و و ميكرومول بر ليتر آهن از منبع كلات آهن نانو (با فرض تأمين بخشى از روى و منخنز، بهترتيب در تيمارهاى T3 و T) منجر به افزايش معنى إر غلظت منخنز و روى ريشه در مقايسه با كاربرد آهن با همين غلظتها از منبع سكوسترين ربا آهن (بهترتيب در تيمارهاى

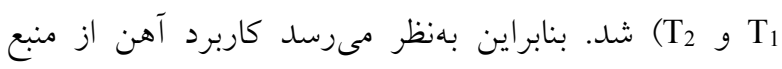
كلات آهن نانو در تأمين غلظت روى و منخنز ريشه مؤثرتر از سكوسترين ^با آهن بوده است (جدول ب). اين در حالى است كه منظرى توكلى و همكاران (Yo) عدم وجود تفاوت معنى دار بين غلظت روى ريشه در كياهان كاهوى تغذيه شده با سكوسترين ربا آهن و نانوكلات آهن را گزارش كردند. شايان ذكر است كاربرد آهن با غلظت \& \& ميكرومول بر ليتر از منبع كلات آهن نانو با فرض عدم تأمين بخشى از روى و منگنز (تيمار T6) باعث كاهش معنى نسبت به كاربرد آهن با همين غلظت از منبع كالات آهن نانو با فرض تأمين بخشى از روى و منگنز (تيمار T5) شد (جدول س).

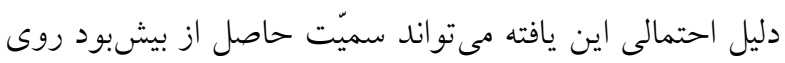


روى بخش هوايى كاهو تأثير بيشترى داشته است. اين يافته

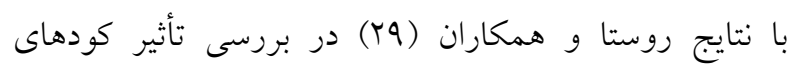
مختلف آهن بر رشد كاهو در كشت بدون خاك مبنى بر تأثير

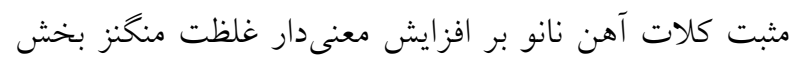

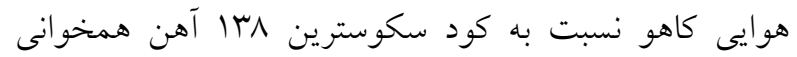

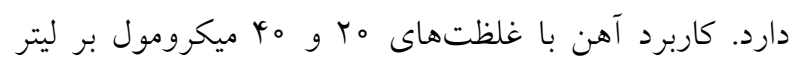
آهن از منبع سكوسترين ربا آهن (بهترتيب در تيمارهاى

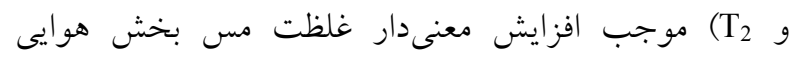

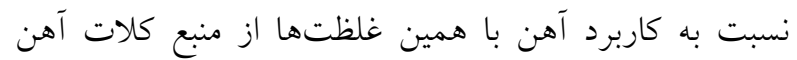

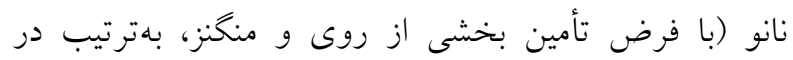

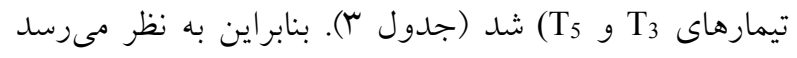

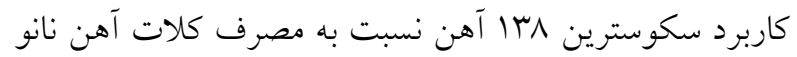
تأثير بيشترى بر افزايش غلظت مس بخش هوايى كاهو داشته است. در همين زمينه كزارش شده است كاربرد سكوسترين ^با آهن نسبت به كلات آهن نانو منجر به افزايش معنى دمار

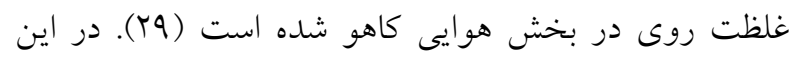

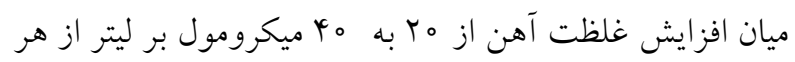

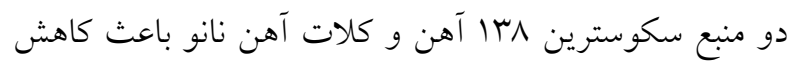
معنىدار غلظت مس بخش هوايى كاهو شد (جدول ساب). دليل

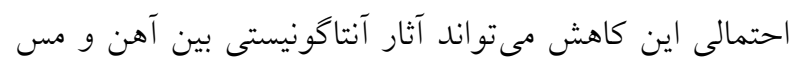

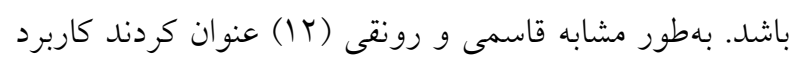

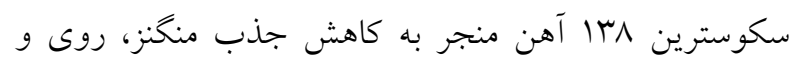
مس در كندم در يك خاك آهكى شد.

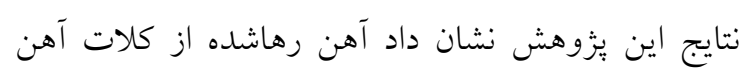
نانو توسط ريشه جذب و به بخش هوايى كاهو منتقل شده سنال

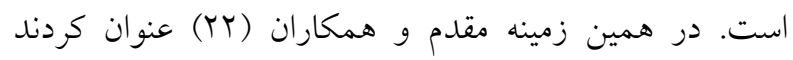

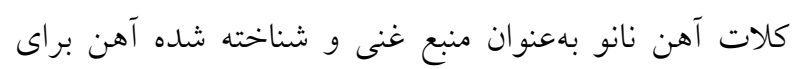

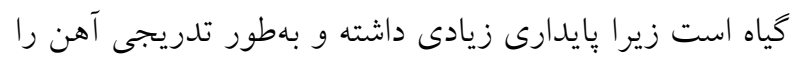

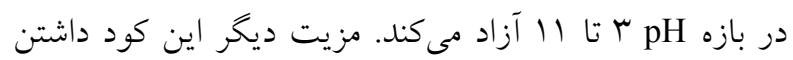
نسبت زياد آهن فرو به فريك است (r|). نانوذرات بهوسيله

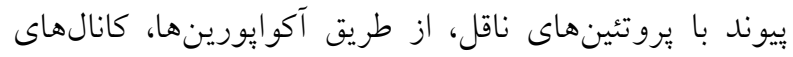
يونى يا اندوسيتوز وارد سلولها مىشوند. همجنين نانوذرات
بين غلظت آهن بخش هوايى كاهو در كياهان كوددهى شده با

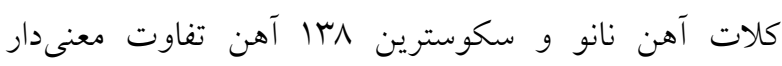

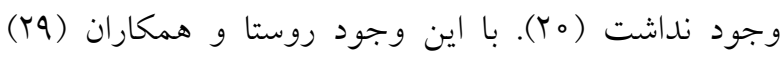

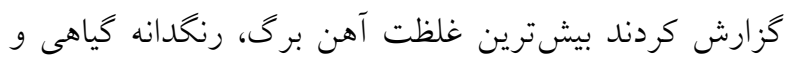

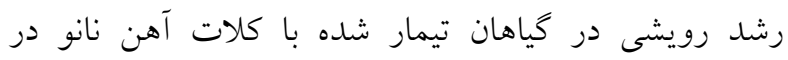

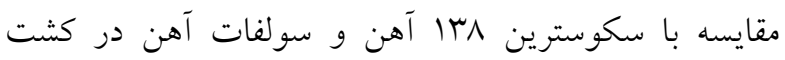
هيدرويونيك كاهو مشاهده شد. بلطور مشابه كاربرد نانوذرات

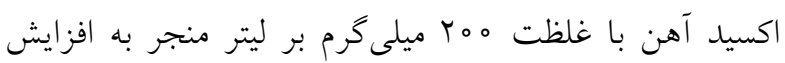

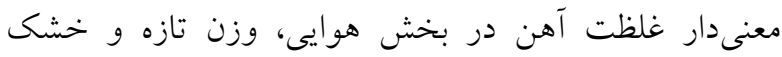

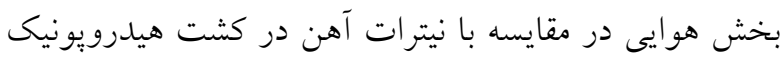

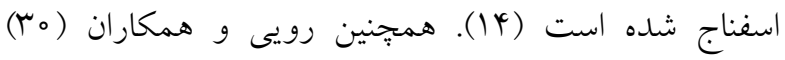

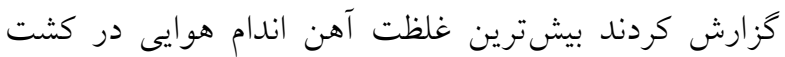

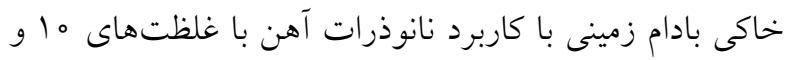

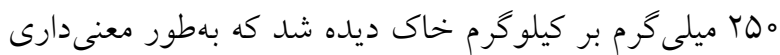

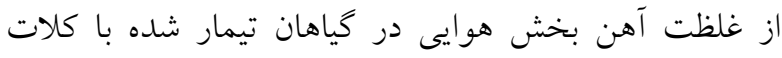

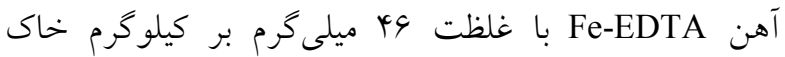
بيشتر بود.

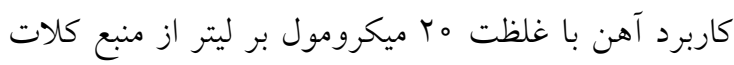
آهن نانو با فرض عدم تأمين بخشى از روى و منكخنز (تيمار

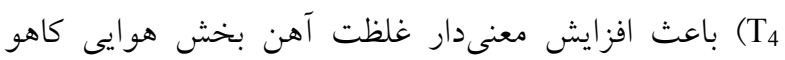

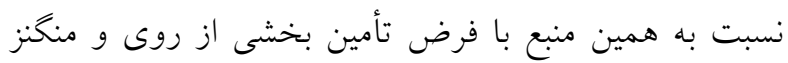

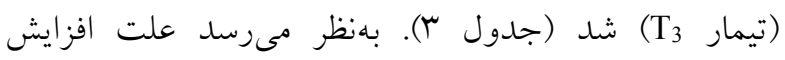
غلظت آهن، كاهش رشد بخش هوايى كاهو ناشى از سميّت

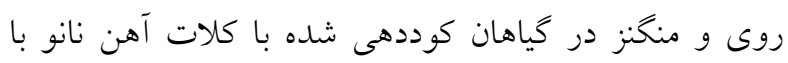

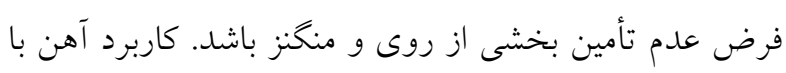

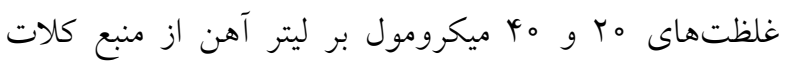

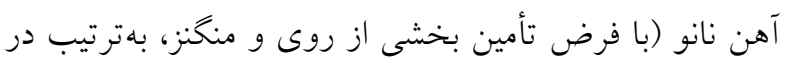

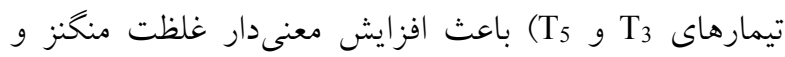
روى بخش هوايى كاهو نسبت به كاربرد آهن با همين غلظتها از منبع سكوسترين ربا آهن (بهترتيب در تيمارهاى شد (جد $T_{2} T_{1}$ نانو نسبت به سكوسترين ربا آهن در افزايش غلظت منخنز و 
جدول f. تجزيه واريانس (ميانخين مربعات) تأثير تيمار كودى و رقم بر رنخيزههاى فتوسنتى برگ، وزن تازه ريشه و بخش هوايى كاهو.

Table 4. Variance analysis (mean squares) for the effects of fertilizer treatment and cultivar on leaf photosynthetic pigments, and root and shoot fresh weights of lettuce.

\begin{tabular}{|c|c|c|c|c|c|c|c|}
\hline \multicolumn{2}{|c|}{$\begin{array}{c}\text { وزن تازه } \\
\text { Fresh weight } \\
\end{array}$} & \multirow[t]{2}{*}{$\begin{array}{c}\text { كاروتنوئيد } \\
\text { Carotenoid }\end{array}$} & \multirow[t]{2}{*}{$\begin{array}{c}\text { كلروفيل كل } \\
\text { Total chlorophyll }\end{array}$} & \multirow[t]{2}{*}{$\begin{array}{c}\text { كلروفيل } \text { Chlorophyll b } \\
\text { Chlo }\end{array}$} & \multirow[t]{2}{*}{$\begin{array}{c}\text { a كلروفيل } \\
\text { Chlorophyll a }\end{array}$} & \multirow{2}{*}{ آل درجه } & \multirow[t]{2}{*}{$\begin{array}{l}\text { منابع تغيير } \\
\text { S.O.V }\end{array}$} \\
\hline $\begin{array}{l}\text { بخش هوايى } \\
\text { Shoot }\end{array}$ & ريشه & & & & & & \\
\hline $23240^{* *}$ & $144.4^{\text {ns }}$ & $0.004^{\mathrm{ns}}$ & $0.022^{\mathrm{ns}}$ & $0.0036^{*}$ & $0.0028^{\mathrm{ns}}$ & 5 & $\begin{array}{l}\text { Fertilizer treatment } \\
\text { Fودار كوى }\end{array}$ \\
\hline $26896^{* *}$ & $3.36^{\mathrm{ns}}$ & $0.014^{*}$ & $0.009^{\text {ns }}$ & $0.0004^{\mathrm{ns}}$ & $0.012^{*}$ & 1 & $\begin{array}{c}\text { رقم كاهو } \\
\text { Lettuce cultivar }\end{array}$ \\
\hline $3330^{\mathrm{ns}}$ & $145.6^{\mathrm{ns}}$ & $0.005^{*}$ & $0.020^{\mathrm{ns}}$ & $0.0023^{\mathrm{ns}}$ & $0.004^{\mathrm{ns}}$ & 5 & $\begin{array}{l}\text { تيمار كودى × رقم كاهو } \\
\text { Fertilizer treatment } \\
\text { Lettuce cultivar }\end{array}$ \\
\hline 1937 & 97.5 & 0.002 & 0.013 & 0.0010 & 0.0027 & 24 & $\begin{array}{l}\text { اط } \\
\text { Error }\end{array}$ \\
\hline
\end{tabular}

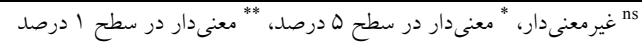

${ }^{n s}$ Non significant, * Significant at 5\%, ${ }^{* *}$ Significant at 1\%

تأثير تيمارهاى آزمايشى بر ميزان رنخيزههاى فتوسنتى برگ كاهو: نتايج تجزيه واريانس نشان داد تنها اثر رقم كاهو بر ميزان كلروفيل a برى در سطح احتمال ينج درصد معنىدار شد (جدول \&). بهطورى كه مقدار كلروفيل a برى در رقم

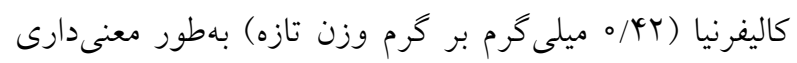
بيشتر از رقم ترسا ( ^س/ه ميلى گرم بر گرم وزن تازه) بود. تفاوت بين ارقام كاهو از نظر ميزان كلروفيل كل و كاروتنوئيد برى در ياسخ به كودهاى مختلف آهن در يزّوهش روستا و همكاران (Y9) نيز گزارش شده است. بر اساس نتايج، اثر تيمار كودى بر ميزان كلروفيل b برى كاهو در سطح احتمال ينج درصد معنىدارى شد. درحالى كه اثر رقم كاهو و

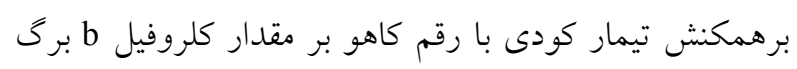

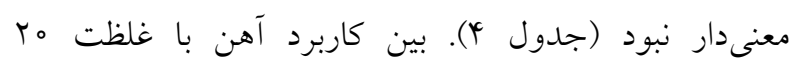
ميكرومول بر ليتر از منبع كلات آهن نانو (با فرض تأمين بخشى از روى و منخنز، تيمار T3) با كاربرد آهن با همين

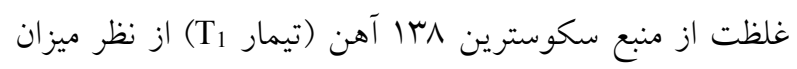
كلروفيل b برى تفاوت معنىدارى وجود نداشت. اما كاربرد آهن با غلظت ب م ميكرومول بر ليتر آهن از منبع سكوسترين

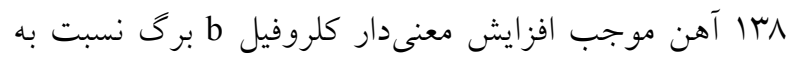
كاربرد آهن با همين غلظت از منبع كلات آهن نانو (با فرض
ممكن است با ناقلين غشا يا ترشحات ريشه، تشكيل كميلكس داده و متعاقب آن بتوانند به درون كياهان منتقل شوند (YY). در همين زمينه باستانى و همكاران (ه) گزارش كردند احتمالاً كميلكس آهن نانو توانايى زيادترى در برهمكنش با ناقلين و آنزيم فريك كلات ردوكتاز ريشه نسبت به آهن حاصله از Fe-EDTA داشته باشد. اين مكانيسم بهعنوان يايهاى براى كارايى بيشتر كلاتهاى آهن در مقايسه با نمكهاى آهن بيشنهاد شده است (19). تحرك بيشتر آهن نانو نسبت به Fe-EDTA در ريشه يا برى نيز مىتواند به تثبيت كمتر آهن در ريشه و آيويلاست برى مربوط باشد. فرض بر اين است كه آهن نانو بهدليل اندازه كمتر و تحرك بيشتر، كمتر در معرض رسوب

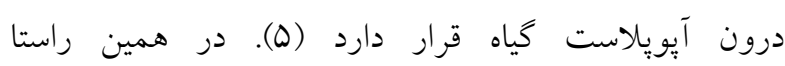
يزوهشهاى انجام شده در اسفناج حاكى از افزايش ميزان توليد بهدليل جذب آهن نانو از طريق ريشهها و سيس انتقال آن به قسمتهاى هوايى است (Y (1). نتايج اين بيزوهش نشان داد غلظت آهن، منگنز و روى در ريشه بيشتر از غلظت اين لهوني عناصر در بخش هوايى كاهو بود. غلظت بيشتر اين عناصر در ريشه بهواسطه نقش تارهاى كشنده بهعنوان اولين مسير جذب عناصر غذايى از محيط رشد است (ه (). 


$$
\text { جدول ه. مقايسه ميانخين تأثير تيمار كودى بر ميزان كلروفيل b برگ، كلروفيل كل برى و كاروتنوئيد برى ارقام كاهو. }
$$

Table 5. Mean comparisons of the effect of fertilizer treatment on leaf chlorophyll b, leaf total chlorophyll and leaf carotenoid of lettuce cultivars.

\begin{tabular}{|c|c|c|c|c|c|}
\hline \multirow{5}{*}{$\begin{array}{l}\text { تيمار كودى } \\
\text { Fertilizer } \\
\text { treatment }\end{array}$} & \multirow{5}{*}{$\begin{array}{c}\text { غلظت آهن } \\
\text { غيكرومول بر ليتر) } \\
\text { Fe concentration } \\
\left(\mu \mathrm{mol} \mathrm{L}{ }^{-1}\right)\end{array}$} & \multirow{5}{*}{ 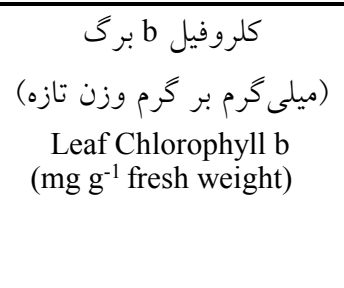 } & \multirow{5}{*}{$\begin{array}{c}\text { كلروفيل كل برگ } \\
\text { كيلى گرم بر وزن تازه) } \\
\text { Leaf total chlorophyll } \\
\text { (mg g-1 fresh weight) }\end{array}$} & \multicolumn{2}{|c|}{ كاروتنوئيد برى } \\
\hline & & & & \multicolumn{2}{|c|}{ (ميلى گرم بر گرم وزن تازه) } \\
\hline & & & & \multicolumn{2}{|c|}{$\begin{array}{c}\text { Leaf carotenoid } \\
\left(\mathrm{mg} \mathrm{g}^{-1} \text { fresh weight }\right)\end{array}$} \\
\hline & & & & ترسا & كاليفرنيا \\
\hline & & & & Teresa & California \\
\hline $\mathrm{T}_{1}$ & 20 & $0.29^{\mathrm{ab}}$ & $0.63^{\mathrm{a}}$ & $0.18^{\mathrm{b}}$ & $0.25^{\mathrm{b}}$ \\
\hline $\mathrm{T}_{2}$ & 40 & $0.31^{\mathrm{a}}$ & $0.70^{\mathrm{a}}$ & $0.18^{\mathrm{b}}$ & $0.24^{\mathrm{b}}$ \\
\hline $\mathrm{T}_{3}$ & 20 & $0.33^{\mathrm{a}}$ & $0.73^{\mathrm{a}}$ & $0.20^{\mathrm{b}}$ & $0.35^{\mathrm{a}}$ \\
\hline $\mathrm{T}_{4}$ & 20 & $0.33^{\mathrm{a}}$ & $0.81^{\mathrm{a}}$ & $0.24^{b}$ & $0.23^{b}$ \\
\hline $\mathrm{T}_{5}$ & 40 & $0.27^{\mathrm{b}}$ & $0.68^{\mathrm{a}}$ & $0.21^{\mathrm{b}}$ & $0.19^{\mathrm{b}}$ \\
\hline $\mathrm{T}_{6}$ & 40 & $0.30^{\mathrm{ab}}$ & $0.74^{\mathrm{a}}$ & $0.20^{\mathrm{b}}$ & $0.21^{\mathrm{b}}$ \\
\hline
\end{tabular}

تاهن

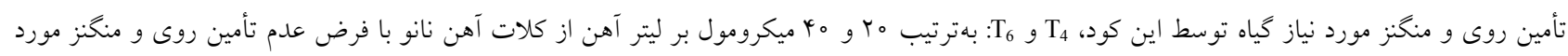

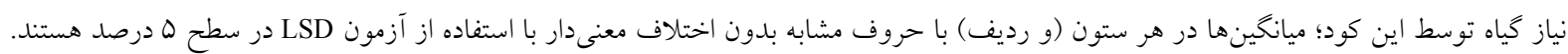
$\mathrm{T}_{1}$ and $\mathrm{T}_{2}: 20$ and $40 \mu \mathrm{mol} \mathrm{L} \mathrm{L}^{-1}$ of Fe from Fe-EDDHA, respectively, $\mathrm{T}_{3}$ and $\mathrm{T}_{5}: 20$ and $40 \mu \mathrm{mol} \mathrm{L}^{-1}$ of Fe from nano iron chelate, respectively

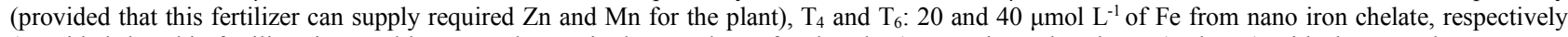
(provided that this fertilizer is not able to supply required $\mathrm{Zn}$ and $\mathrm{Mn}$ for the plant); Data in each column (and row) with the same letter are not statistically different at 0.05 probability level based on LSD Test.

آهن نانو (با فرض تأمين بخشى از روى و منخنز، تيمار T5) و

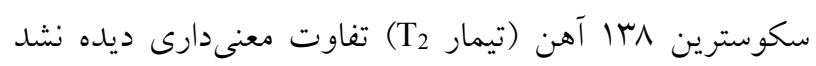
(جدول ه). اين مسئله نشاندهنده آنست كه هر دو كود كلات آهن نانو و سكوسترين ربا آهن با تأمين آهن مورد نياز كياه، تأثير يكسانى بر ميزان كارتنوئيد برگ داشتهاند. كياهان براى كاركرد بهينه سيستم فتوسنتزى به عناصرى مانند

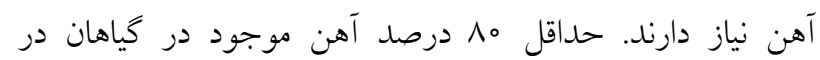
برگها جاى دارد كه عنصرى كليدى در فرايند انتقال الكترون در فتوستنز است (1)). هر دو كلروفيل a و b نقش مهمى در فتوستز به واسطه جذب نور از طريق سيستم انتقال الكترون دارند كه اين نقش از طريق بروتئينهاى حاوى آهن و گو گرد ايفا مىشود (بr). يروتئينهاى حاوى آهن و گوكرد از خوشههاى Fe-S تشكيل شده و وظيفه اصلى آنها انتقال الكترون از طريق وضعيتهاى اكسايشى

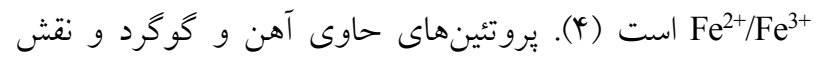
آنها در توليد كلروفيل جزو مراحل حياتى در فرآيند توليد انرزى، رشد و توسعه گياهان است (Y). يُزوهشهاى بيشين نشان مى بـهند

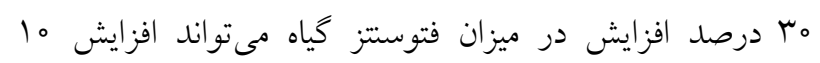
درصدى در رشد نسبى كياه ايجاد كند (9). مشابه با نتايج اين
تأمين بخشى از روى و منگنز، تيمار T5) شد (جدول ه). اين مسئله نشاندهنده آن است كه در غلظت آ ميكرومول بر ليتر آهن، هر دو كود با تأمين آهن مورد نياز كياه تأثير يكسانى بر ميزان كلروفيل b برگ داشته اما در غلظت مث ميكرومول بر ليتر، تأثير سكوسترين ^با آهن بر افزايش ميزان كلروفيل برگ از كلات آهن نانو بيشتر بوده است. نتايج تجزيه واريانس نشان داد اثر تيمار كودى، رقم كاهو و برهمكنش آنها بر كلروفيل كل برى معنىدار نبود (جدول †). نتايج تجزيه واريانس نشان داد اثر رقم كاهو و برهمكنش تيمار كودى با رقم كاهو بر ميزان كارتنوئيد برگ در سطح احتمال ينج درصد معنىدار شد (جدول \&)). در رقم ترسا بين ميزان كارتنوئيد برى

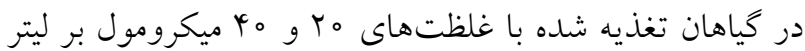
آهن از منبع كلات آهن نانو (با فرض تأمين بخشى از روى و منكنز، بهترتيب در تيمارهاى T3 و T5 ) و كياهان تغذيه شده با همين غلظتها از منبع سكوسترين رسا آهن (بهترتيب در

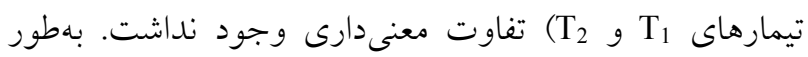
مشابه نيز در رقم كاليفرنيا بين ميزان كارتنوئيد برى در گياهان تغذيه شده با غلظت ب ميكرومول بر ليتر آهن از منبع كلات 
تأثير تيمارهاى آزمايشى بر وزن تازه ريشه و بخش هوايى كاهو:

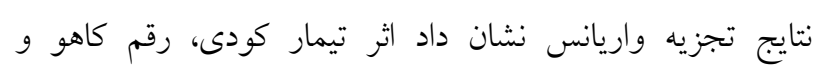
برهمكنش آنها با همديخر بر وزن تازه ريشه كاهو معنى دار نشد.

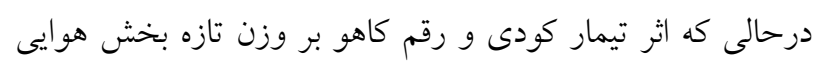

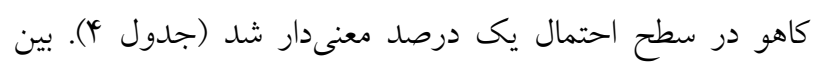

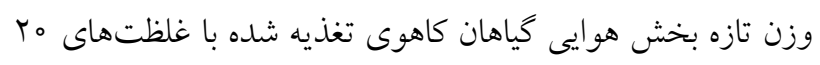

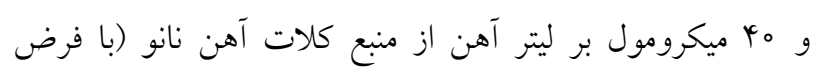

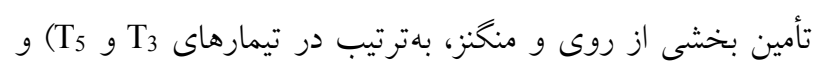

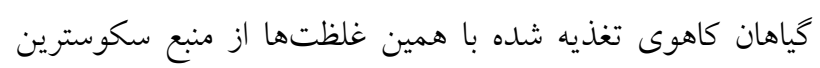

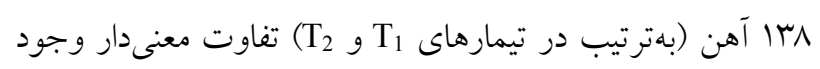
نداشت (جدول 9). اين مسئله نشاندهنده كارايى يكسان كلات

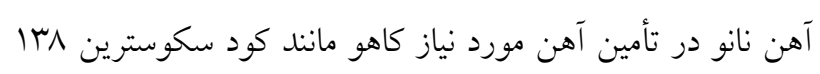
آهن براى دستيابى به عملكرد مطلوب است. در همخوانى با نتايج

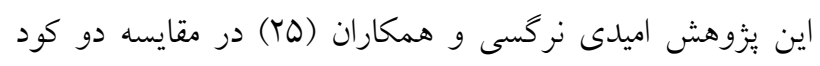

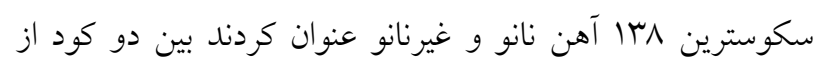

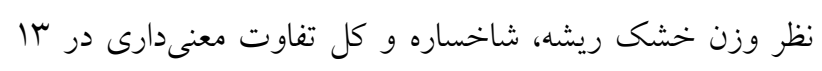

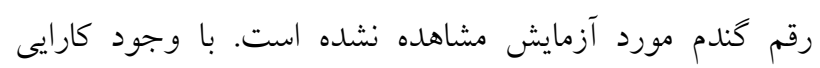

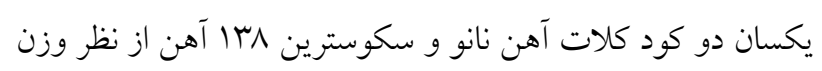

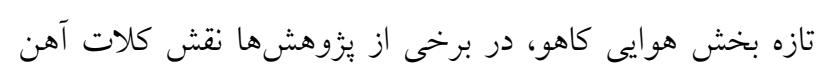

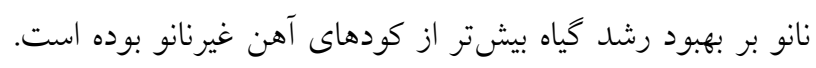
در اين زمينه عسكرى و همكاران (r) گزارش كردند طول ريشه،

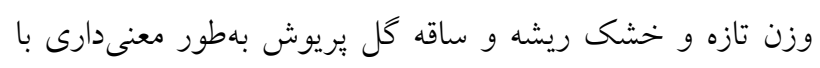

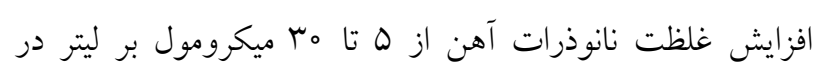
مقايسه با كلات آهن Fe-EDTA افزايش يافت. روستا و همكاران

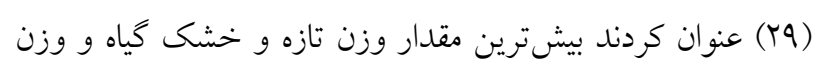

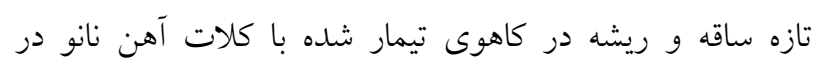

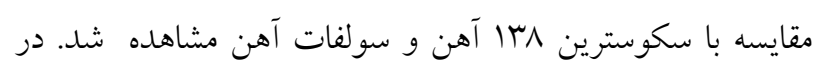

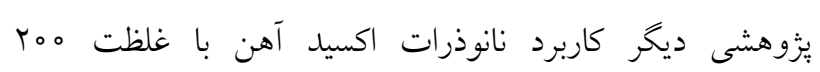

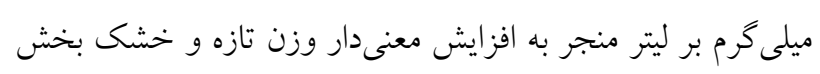

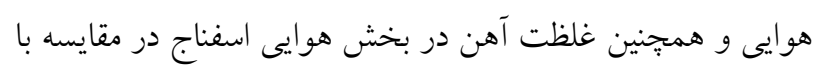

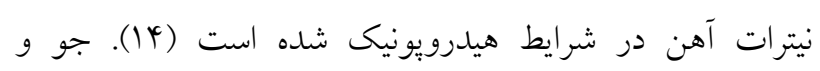
همكاران (ه) كزارش كردند كاربرد نانوذرات اكسيد آهن با اندازه
يُزوهش، نعمتى و همكاران (YY) گزارش كردند تغذيه بركى

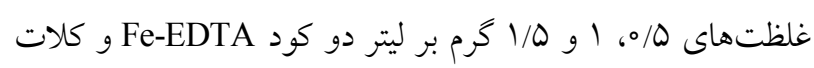

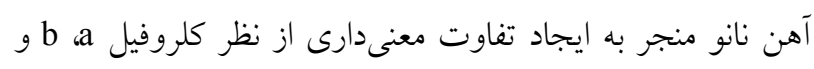

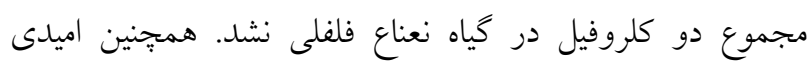

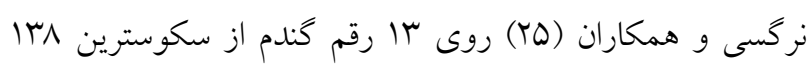

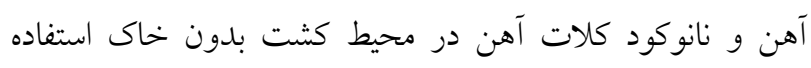

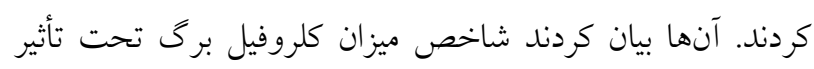

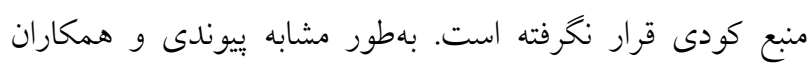
(TV)

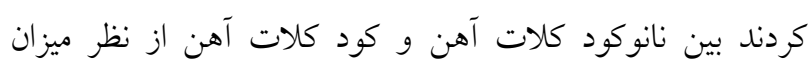

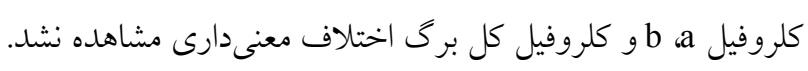

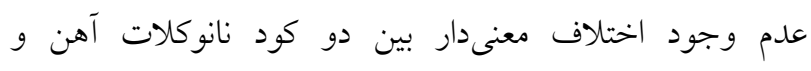

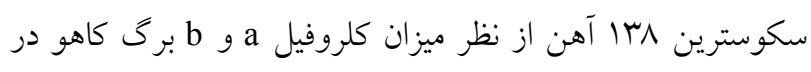

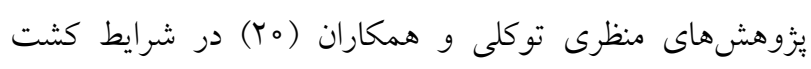

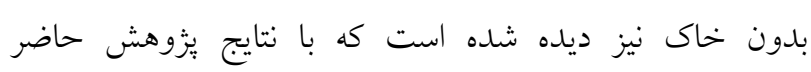

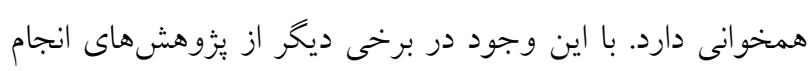

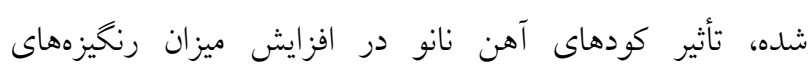

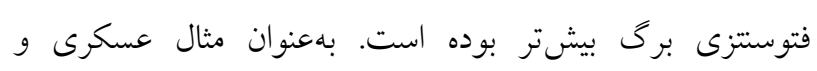

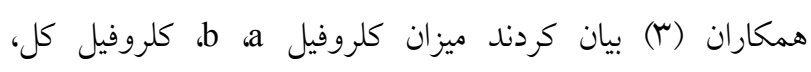

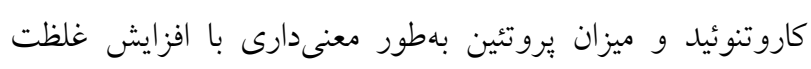
نانوذرات آهن از ه تا مب ميكرومول بر ليتر در مقايسه با كاربرد Fe-EDTA

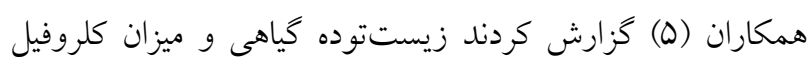

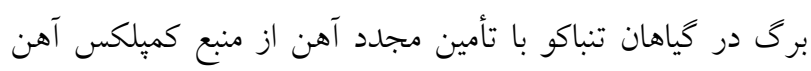

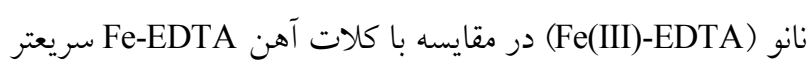

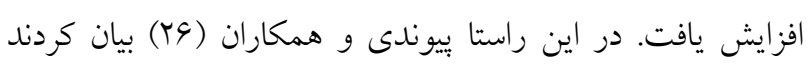

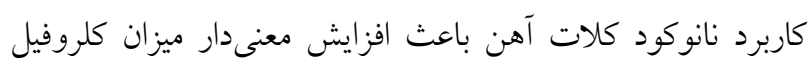

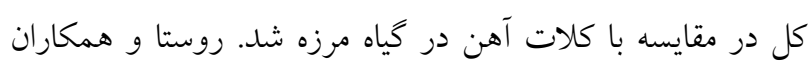

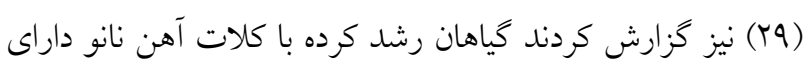

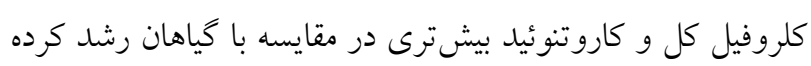
با سكوسترين رسا آهن بودند. 


$$
\text { جدول 9. مقايسه ميانخين تأثير تيمار كودى بر وزن تازه ريشه و بخش هوايى ارقام كاهو. }
$$

Table 6. Mean comparisons of the effect of fertilizer treatment on root and shoot fresh weights of lettuce cultivars.

\begin{tabular}{|c|c|c|c|c|}
\hline \multirow{2}{*}{$\begin{array}{l}\text { تيمار كودى } \\
\text { Fertilizer } \\
\text { treatment }\end{array}$} & \multirow[t]{2}{*}{ غلظت آهن (ميكرومول بر ليتر) } & \multicolumn{2}{|c|}{ 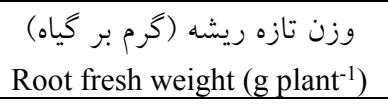 } & \multirow{2}{*}{$\begin{array}{c}\text { وزن تازه بخش هوايى } \\
\text { وخرم بر گياه) } \\
\text { Shoot fresh weight } \\
\quad\left(\text { g plant }{ }^{-1}\right)\end{array}$} \\
\hline & & $\begin{array}{c}\text { ترسا } \\
\text { Teresa }\end{array}$ & $\begin{array}{c}\text { كاليفرنيا } \\
\text { California }\end{array}$ & \\
\hline $\mathrm{T}_{1}$ & 20 & $80.0^{\mathrm{a}}$ & $69.0^{\mathrm{a}}$ & $415^{\mathrm{ab}}$ \\
\hline $\mathrm{T}_{2}$ & 40 & $66.0^{\mathrm{a}}$ & $68.0^{\mathrm{a}}$ & $436^{\mathrm{a}}$ \\
\hline $\mathrm{T}_{3}$ & 20 & $67.0^{\mathrm{a}}$ & $57.6^{\mathrm{a}}$ & $365^{\mathrm{b}}$ \\
\hline $\mathrm{T}_{4}$ & 20 & $65.6^{\mathrm{a}}$ & $61.3^{\mathrm{a}}$ & $275^{\mathrm{c}}$ \\
\hline $\mathrm{T}_{5}$ & 40 & $64.0^{\mathrm{a}}$ & $79.6^{\mathrm{a}}$ & $387^{\mathrm{ab}}$ \\
\hline $\mathrm{T}_{6}$ & 40 & $62.6^{\mathrm{a}}$ & $66.0^{\mathrm{a}}$ & $308^{c}$ \\
\hline
\end{tabular}

تأسن

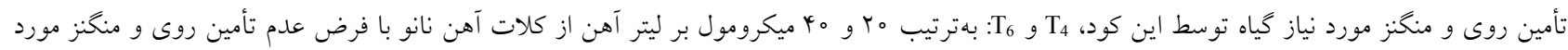

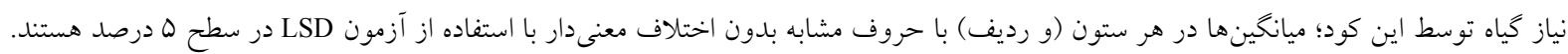
$\mathrm{T}_{1}$ and $\mathrm{T}_{2}: 20$ and $40 \mu \mathrm{mol} \mathrm{L} \mathrm{L}^{-1}$ of Fe from Fe-EDDHA, respectively, $\mathrm{T}_{3}$ and $\mathrm{T}_{5}: 20$ and $40 \mu \mathrm{mol} \mathrm{L}^{-1}$ of Fe from nano iron chelate, respectively (provided that this fertilizer can supply required $\mathrm{Zn}$ and $\mathrm{Mn}$ for the plant), $\mathrm{T}_{4}$ and $\mathrm{T}_{6}: 20$ and $40 \mu \mathrm{mol} \mathrm{L}^{-1}$ of Fe from nano iron chelate, respectively (provided that this fertilizer is not able to supply required $\mathrm{Zn}$ and $\mathrm{Mn}$ for the plant); Data in each column (and row) with the same letter are not statisticallydifferent at 0.05 probability level based on LSD Test.

مسئله احتمالاً بهدليل بروز سمّيت ناشى از بيشبود دو عنصر

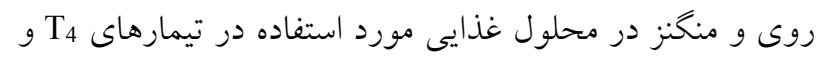

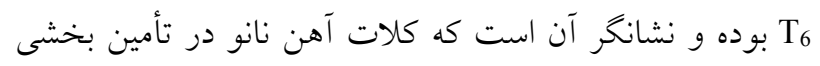

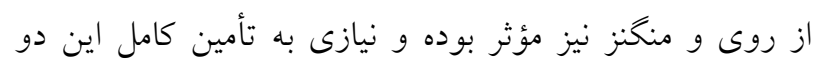

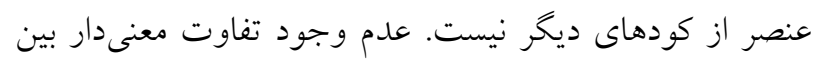

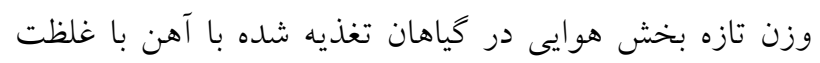

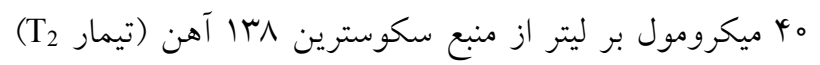

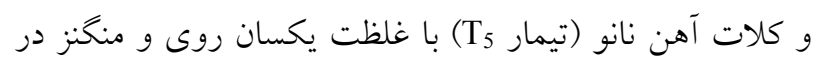
محلول غذايى، نشاندهنده نقش مؤثر نانوكود در تأمين و و

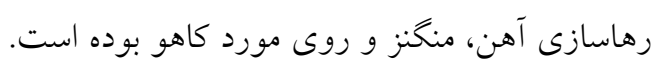

\section{نتيجه گيرى}

نتايج اين يزّوهش نشان داد كلات آهن نانو همجيجون سكوسترين

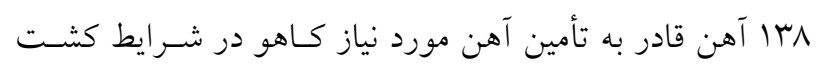

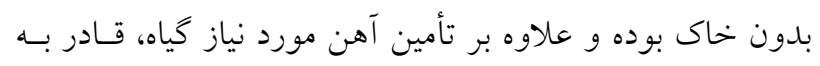

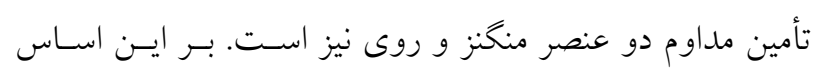

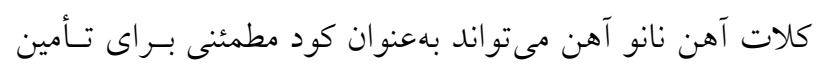

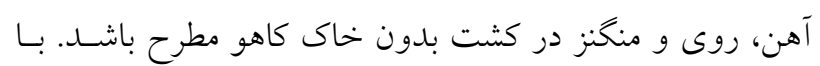

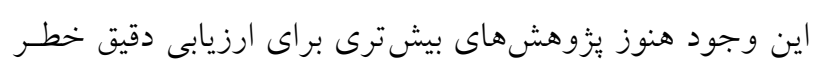
بالقوه آن براى محيط زيست و امنيت غذايى مورد نياز است.

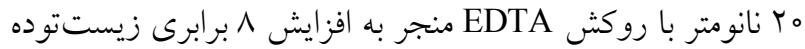

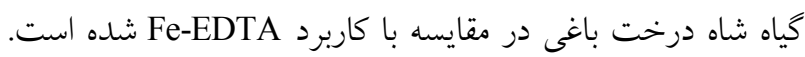

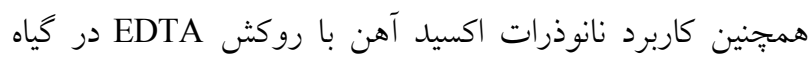
شاه درخت باغى باعث افزايش ^ برابرى زيستتوده كل و افزايش

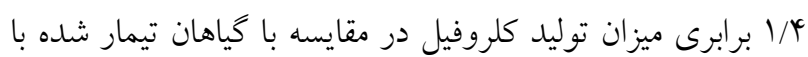

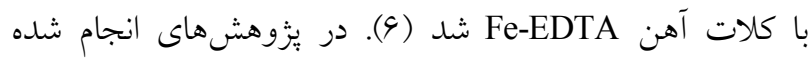

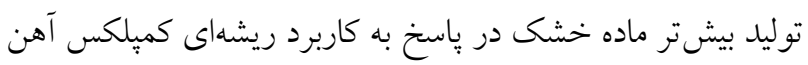

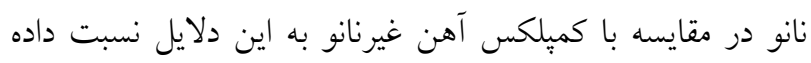

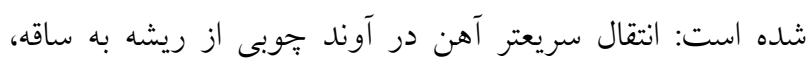

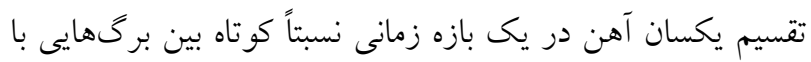

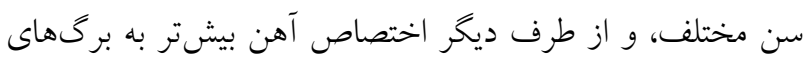

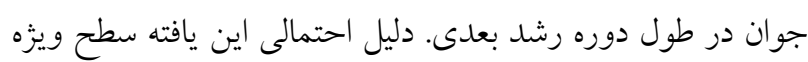

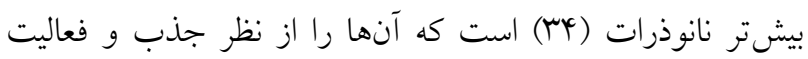
بهتر از نمونهاى غيرنانو خود مى كند (ه).

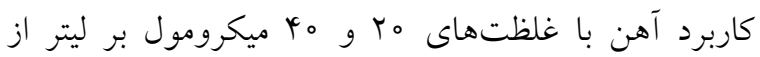

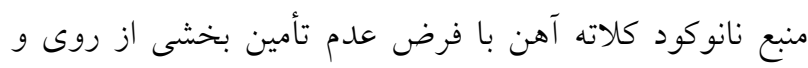

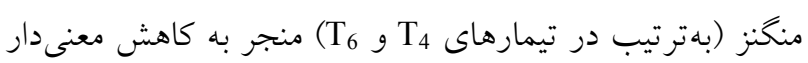

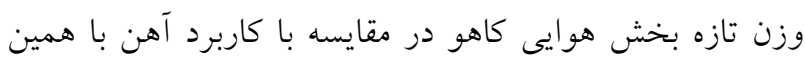

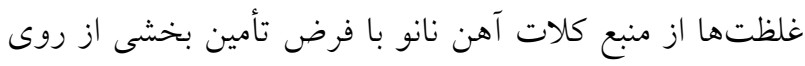

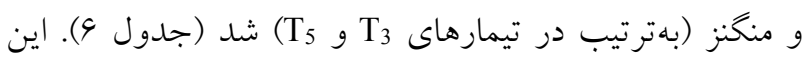




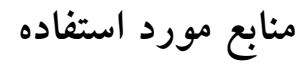

1. Albano, J.P., Miller, W.B., 2001. Photodegradation of Fe DTPA in nutrient solutions, effects of irradiance, wavelength and temperature. HortScience 36: 313-316.

2. Ali Ehyayi, M., Behbehanizadeh, A.A., 1993. Methods of Soil Analysis. Soil and Water Research Institute Press, Tehran. (in Persian)

3. Askary, M., Amirjani. M.R., Saberi, T., 2017. Comparison of the effects of nano-iron fertilizer with iron-chelate on growth parameters and some biochemical properties of Catharanthus roseus. Journal of Plant Nutrition 40: 974-982.

4. Balk, J., Lobreaux, S., 2005. Biogenesis of iron-sulfur proteins in plants. Trends in Plant Science 10(7): 324-331.

5. Bastani, S., Hajiboland, R., Khatamian, M., Saket-Oskoui, M., 2018. Nano iron (Fe) complex is an effective source of Fe for tobacco plants grown under low Fe supply. Journal of Soil Science and Plant Nutrition 18 (2): 524-541.

6. Boutchuen, A., Zimmerman, D., Aich, N., Mohammad Masud, A., Arabshahi, A., Palchoudhury, S., 2019. Increased plant growth with hematite nanoparticle fertilizer drop and determining nanoparticle uptake in plants using multimodal approach. Journal of Nanomaterials. 2019: 1-11. doi.org/10.1155/2019/6890572.

7. Dekreij, C., Voogt, W., Baas, R., 2003. Nutrient Solutions and Water Quality for Soilless Cultures. Research Station for Floriculture and Greenhouse Vegetables, Naaldwijk.

8. DeRosa, M.C., Monreal, C., Schnitzer, M., Walsh, R., Sultan, Y., 2010. Nanotechnology in fertilizers. Nature Nanotechnology 5: 91-94.

9. Elanchezhian, R., Kumar, D., Ramesh, K., Kumar Biswas, A., Guhey, A., Kumar Patra. A., 2017. Morphophysiological and biochemical response of maize (Zea mays L.) plants fertilized with nano-iron $\left(\mathrm{Fe}_{3} \mathrm{O}_{4}\right)$ micronutrient. Journal of Plant Nutrition 40(14): 1969-1977.

10. Emami, A., 1996. Methods of Plant Analysis. Soil and Water Research Institute Press, Tehran, 128 pp. (in Persian)

11. Ghafariyan, M.H., Malakouti, M.J., Dadpour, M.R., Stroeve, P., Mahmoudi, M., 2013. Effects of magnetite nanoparticles on soybean chlorophyll. Environmental Science and Technology 47(18): 10645-10652.

12. Ghasemi Fasaei, R., Ronaghi, A., 2008. Interaction of iron with copper, zinc, and manganese in wheat as affected by iron and manganese in a calcareous soil. Journal of Plant Nutrition 31(5): 839-848.

13. Hokmabadi, H., Haidarinezad, A., Barfeie, R., Nazaran, M., Ashtian, M., Abotalebi, A., 2006. A new iron chelate introduction and their effects on photosynthesis activity, chlorophyll content and nutrients upake of pistachio (Pistacia vera L.). In: $27^{\text {th }}$ International Horticaltural Congress and Exhibitions, Seoul, Korea, August 13-19.

14. Jeyasubramanian, K., Upeksha Gopalakrishnan Thoppey, U., Sobhin Hikku, G., Selvakumar, N., Subramania, A., Krishnamoorthy, K., 2016. Enhancement in growth rate and productivity of spinach grown in hydroponics with iron oxide nanoparticles. RSC Advances 6: 15451-15459.

15. Ju, M., Navarreto-Lugo, M., Wickramasinghe, S., Milbrandt, N.B., McWhorter, A., Samia, A.C.S., 2019. Exploring the chelation-based plant strategy for iron oxide nanoparticle uptake in garden cress (Lepidium sativum) using magnetic particle spectrometry. Nanoscale. 11: 18582-18594. doi.org/10.1039/c9nr05477d.

16. Kirschbaum, M.U.F., 2011. Does enhanced photosynthesis enhance growth? Lessons learned from $\mathrm{CO}_{2}$ enrichment studies. Plant Physiology 155(1): 117-124.

17. Liu, X., Feng, Z., Zhang, S., Zhang, J., Xiao, Q., Wang, Y., 2006. Preparation and testing of cementing nanosubnano composites of slow or controlled release of fertilizers. Scientia Agriculture Sinica 39: 1598-1604.

18. López-Millán, A.F., Duy, D., Philippar, K., 2016. Chloroplast iron transport proteins - function and impact on plant physiology. Frontiers in Plant Science 7: 1-12. doi.org/10.3389/fpls.2016.00178.

19. Lucena, J.J., Hernandez-Apaolaza, L., 2017. Iron nutrition in plants: an overview. Plant and Soil 418: 1-4.

20. Manzari Tavakoli, M., Bagheri, V., Roosta, H., 2015. Comparison of efficiency of different Fe sources on growth and physiological characteristics of lettuce under alkaline conditions in hydroponic system. Journal of Soil and Plant Interactions 5(4): 41-49. (in Persian with English abstract)

21. Marschner, H., 1995. Mineral Nutrition of Higher Plants. Second ed., Academic Press, London.

22. Moghadam, A., Vattani, H., Baghaei, N., Keshavarz, N., 2012. Effect of different levels of fertilizer nano-iron chelates on growth and yield characteristics of two varieties of spinach (Spinacia oleracea L.): Varamin 88 and Viroflay. Research Journal of Applied Sciences, Engineering and Technology 4(12): 4813-4818.

23. Mohamadipoor, R., Sedaghathoor, S., Mahboub-Khomami, A., 2013. Effect of application of iron fertilizers in two methods 'foliar and soil application' on growth characteristics of Spathyphyllum illusion. European Journal of Experimental Biology 3(1): 232-240.

24. Nemati Lafmejani, Z., Ashraf Jafari, A., Moradi, P., Ladan Moghadam, A., 2018. Impact of foliar application of iron-chelate and iron nano particles on some morpho-physiological traits and essential oil composition of peppermint (Mentha piperita L.,). Journal of Essential Oil Bearing Plants 21(5): 1374-1384.

25. Omidi Nargesi, S., Zahedi, M., Eshghizadeh, H.R., Khoshgoftarmanesh, A.H., 2015. Screening wheat genotypes in 
response to ordinary chelate and nano-iron chelate fertilizers in nutrient solution. Journal of Soil and Plant Interactions 6(4): 123-133. (in Persian with English abstract)

26. Peyvandi, M., Kamali Jamakani, Z., Mirza, M., 2012. The effect of nano Fe chelate and Fe chelate on the growth and activity of some antioxidant enzymes of Satureja hortensis. New Cellular and Molecular Biotechnology Journal 5: 25-32. (in Persian with English abstract)

27. Peyvandi, M., Parande, H., Mirza, M., 2011. Comparison of nano Fe chelate with Fe chelate effect on growth parameters and antioxidant enzymes activity of Ocimum basilicum. New Cellular and Molecular Biotechnology Journal 4: 89-98. (in Persian with English abstract)

28. Pozveh, Z.T., Roya, R. Fatemeh, R., 2014. Changes occurring in canola (Brassica napus L.) in response silver nanoparticles treatment under in vitro conditions. Indian Journal of Fundamental and Applied Life Sciences 4: 797-807. 29. Roosta, H.R., Jalali, M., Vakili Shahrbabaki, S.M.A., 2015. Effect of nano Fe-chelate, Fe-EDDHA and FeSO 4 on vegetative growth, physiological parameters and some nutrient elements concentrations of four varieties of lettuce (Lactuca sativa L.) in NFT system. Journal of Plant Nutrition 38(14): 2176-2184.

30. Rui, M., Ma, C., Hao, Y., Guo, J., Rui, Y., Tang, X., Zhao, Q., Fan, X., Zhang, Z., Hou, T., Zhu, S., 2016. Iron oxide nanoparticles as a potential iron fertilizer for peanut (Arachis hypogaea). Frontiers in Plant Science 7: 1-10. doi.org/10.3389/fpls.2016.00815.

31. Saini, R.S., Sharma, K.D., Dhankhar, O.P., Kaushik, R.A., 2001. Laboratory Manual of Analytical Techniques in Horticulture. Agrobios, India.

32. Senge, M.O., Ryan, A.A., Letchford, K.A., MacGowan, S.A. and Mielke, T., 2014. Chlorophylls, symmetry, chirality, and photosynthesis. Symmetry 6(3): 781-843. doi.org/10.3390/sym6030781.

33. Suman, P.R., Jain V.K., Varma, A., 2010. Role of nano materials in symbiotic fungus growth enhancement. Scientific Correspondence 99: 1189-1191.

34. Tripathi, D.K., Singh, S., Singh, S., Pandey, R., Singh, V.P., Sharma, N.C., Prasad, S.M., Dubey, N.K., Chauhan, D.K., 2017. An overview on manufactured nanoparticles in plants: uptake, translocation, accumulation and phytotoxicity. Plant Physiology and Biochemistry, 110: 2-12.

35. Vadas, T.M., Zhang, X., Curran, A.M., Ahner, B.A., 2007. Fate of DTPA, EDTA and EDDS in hydroponic media and effect on plant mineral nutrition. Journal of Plant Nutrition 30: 1229-1246. 


\title{
The Effect of Nano Iron Chelate on the Micronutrients Concentration, Leaf Photosynthetic Pigments and Yield of Lettuce (Lactuca sativa L.) in Soilless Culture
}

\author{
S. Mirzaeyan Dehkordi ${ }^{1}$ Sh. Kiani* and A.R. Hosseinpur
}

(Received: 13 June 2021; Accepted: 31 August 2021)

\begin{abstract}
Sequestrene $138 \mathrm{Fe}$ (Fe-EDDHA), one of the most common fertilizers, is used as a source of iron (Fe) in soilless cultures, but its high price leads to increased production costs. This experiment was conducted to investigate the effect of nano iron chelate (consisting of $\mathrm{Fe}, \mathrm{Zn}$ and $\mathrm{Mn}$ ) in comparison with Fe-EDDHA on the micronutrients concentration, leaf photosynthetic pigments and yield of two lettuce (Lactuca sativa L.) cultivars in soilless culture. A factorial experiment using completely randomized design was carried out with two factors of iron fertilizers and lettuce cultivars (Teresa and California) and three replications at Shahrekord University. Lettuce plants were nourished with 20 and $40 \mu \mathrm{mol} \mathrm{L} \mathrm{L}^{-1}$ of Fe in nutrient solution from sources of Fe-EDDHA and nano iron chelate (provided that this fertilizer can supply or is not able to supply $\mathrm{Zn}$ and $\mathrm{Mn}$ required for the plant). The results indicated no significant difference between the application of $40 \mu \mathrm{mol} \mathrm{L}^{-1}$ of $\mathrm{Fe}$ from either nano iron chelate (provided that this fertilizer can supply $\mathrm{Zn}$ and Mn required for the plant) or Fe-EDDHA fertilizers in respect to leaf chlorophyll and carotenoid contents, root and shoot fresh weights, and shoot $\mathrm{Fe}$ concentrations of the studied lettuce cultivars. Although the highest shoot fresh weight (436 g plant $^{-1}$ ) was obtained in $40 \mu \mathrm{mol} \mathrm{L}^{-1}$ of Fe as Fe-EDDHA, it was not significantly different with shoot fresh weight $\left(387 \mathrm{~g} \mathrm{plant}^{-1}\right)$ gained by application of $40 \mu \mathrm{mol} \mathrm{L}^{-1}$ of Fe as nano iron chelate. Based on the results, nano iron chelate might be an ideal substitution for the Fe-EDDHA in soilless culture of lettuce, however further research is still required to completely evaluate its potential risks to the environment and food safety.
\end{abstract}

Keywords: Leaf chlorophyll, Lettuce cultivars, Nutrient solution, Sequestrene $138 \mathrm{Fe}$.

Background and Objective: Iron $(\mathrm{Fe})$ is one of the essential micronutrients for plant growth and plays an important role in photosynthetic processes. Generally, synthetic-Fe fertilizers are used to supply Fe in nutrient solutions in soilless cultures. Synthetic chelates (i.e., Fe-EDTA, Fe-DTPA and Fe-EDDHA) are effective sources of $\mathrm{Fe}$ for nutrient solutions but they are expensive and vulnerable to photodegradation. Recently, nano iron chelates have been synthesized and used as sources of Fe for plants. In this context, Roosta et al. (1) reported that the highest values of leaf Fe, plant pigments and vegetative growth of lettuce plants were obtained in plants treated with nano iron chelate in nutrient film technique. This research was carried out to elucidate the effect of nano iron chelate in comparison with Fe-EDDHA on the shoot and root

1- Soil Science and Engineering Department, Faculty of Agriculture, Shahrekord University

* Corresponding Author, Email: shkiani2002@yahoo.com 
micronutrients concentration, leaf photosynthetic pigments and yield of two lettuce cultivars.

Methods: A factorial experiment using completely randomized design was conducted with the two factors of iron fertilizers and lettuce cultivars (Teresa and California) and three replications in hydroponic culture. Iron fertilizer treatments were: $\mathrm{T}_{1}$ and $\mathrm{T}_{2}$ indicating 20 and $40 \mu \mathrm{mol} \mathrm{L}^{-1}$ of Fe as Fe-EDDHA, respectively, and $\mathrm{T}_{3}$ and $\mathrm{T}_{5}$ representative of 20 and $40 \mu \mathrm{mol} \mathrm{L} \mathrm{L}^{-1}$ of $\mathrm{Fe}$ as nano iron chelate, respectively (provided that this fertilizer can supply $\mathrm{Zn}$ and $\mathrm{Mn}$ required for the plant). $\mathrm{In}_{3}$ and $\mathrm{T}_{5}$ treatments, part of $\mathrm{Zn}$ and $\mathrm{Mn}$ in the nutrient solution was supplied from nano iron chelate and the remaining amounts were supplied from zinc sulfate and manganese sulfate, respectively. In $\mathrm{T}_{4}$ and $\mathrm{T}_{6}$ treatments, 20 and $40 \mu \mathrm{mol} \mathrm{L}^{-1}$ of Fe as nano iron chelate were applied, respectively (provided that this fertilizer is not able to supply $\mathrm{Zn}$ and Mn required for the plant). In $\mathrm{T}_{4}$ and $\mathrm{T}_{6}$ treatments, all applied amounts of $\mathrm{Zn}$ and $\mathrm{Mn}$ in the nutrient solution were supplied from zinc sulfate and manganese sulfate, respectively, and the ability of nano iron chelate in supplying these elements was ignored. Lettuce seedlings were transferred in $2 \mathrm{~L}$ plastic vessels (one plant per vessel) containing aerated nutrient solutions. Eight weeks after transplanting, chlorophyll $a, b$ and $(a+b)$, and carotenoids were quantified using Saini method (2). Then, plants were harvested and fresh weights of shoot and root were determined. Plant organs were dried and dry weights of shoot and root were measured. Plant samples were ground for nutrient analysis and concentrations of $\mathrm{Fe}, \mathrm{Mn}, \mathrm{Zn}$ and $\mathrm{Cu}$ were measured using atomic absorption spectrometer.

Results: The results revealed no significant difference between the application of $20 \mu \mathrm{mol} \mathrm{L} \mathrm{L}^{-1}$ of Fe from either nano iron chelate or Fe-EDDHA fertilizers in terms of root and shoot $\mathrm{Fe}$ concentrations, leaf total chlorophyll content, leaf chlorophyll $\mathrm{b}$ content as well as shoot fresh weight. Also, addition of $40 \mu \mathrm{mol} \mathrm{L}^{-1}$ of $\mathrm{Fe}$ from nano iron chelate (provided that this fertilizer can supply $\mathrm{Zn}$ and $\mathrm{Mn}$ required for the plant) and $\mathrm{Fe}-$ EDDHA fertilizers had both the same effect on the leaf chlorophyll and carotenoid contents, root and shoot fresh weights and shoot Fe concentration. Results showed that application of 20 and $40 \mu \mathrm{mol} \mathrm{L} \mathrm{L}^{-1}$ of $\mathrm{Fe}$ as nano iron chelate significantly increased $\mathrm{Mn}$ and $\mathrm{Zn}$ contents in root and shoot as compared with $\mathrm{Fe}$ EDDHA. Based on the results, nano iron chelate can release $\mathrm{Zn}$ and $\mathrm{Mn}$ in the nutrient solution for production of lettuce.

Conclusions: The sustainable release of nutrients from nano iron chelate showed that this fertilizer may be used as a source of $\mathrm{Fe}, \mathrm{Zn}$ and $\mathrm{Mn}$ for lettuce plants and could be a promising substitution for Fe-EDDHA in nutrient solutions. Further studies on the potential risk to the environment and food safety of this fertilizer need to be considered.

\section{References:}

1. Roosta, H.R., Jalali, M., Vakili Shahrbabaki, S.M.A., 2015. Effect of nano Fe-chelate, Fe-EDDHA and $\mathrm{FeSO}_{4}$ on vegetative growth, physiological parameters and some nutrient elements concentrations of four varieties of lettuce (Lactuca sativa L.) in NFT system. Journal of Plant Nutrition 38(14): 2176-2184.

2. Saini, R.S., Sharma, K.D., Dhankhar, O.P., Kaushik, R.A., 2001. Laboratory Manual of Analytical Techniques in Horticulture. Agrobios, India. 